NBER WORKING PAPER SERIES

\title{
THE IMPACT OF SCHOOL CHOICE ON STUDENT OUTCOMES: AN ANALYSIS OF THE CHICAGO PUBLIC SCHOOLS
}

\author{
Julie Berry Cullen \\ Brian A. Jacob \\ Steven D. Levitt \\ Working Paper 7888 \\ http://www.nber.org/papers/w7888 \\ NATIONAL BUREAU OF ECONOMIC RESEARCH \\ 1050 Massachusetts Avenue \\ Cambridge, MA 02138 \\ September 2000
}

\begin{abstract}
We would like to thank John Easton of the Consortium on Chicago School Research and the Chicago School Board for providing access to the Chicago Public Schools data. We would also like to express our gratitude to the Chicago Regional Transportation Authority for the use and to Ms. Shayna Sachs of ManTech Systems Solutions Corporation for the processing of the TRIPS data. The National Science Foundation provided financial support. We would also like to gratefully acknowledge Jinyong Hahn, Caroline Hoxby, Susanna Loeb, Bruce Meyer, Kevin Murphy, Chris Taber, and seminar participants from Duke, Northwestern, University of Chicago, University of Michigan, and University of North Carolina for helpful comments. The views expressed herein are those of the authors and not necessarily those of the National Bureau of Economic Research.
\end{abstract}

(C) 2000 by Julie Berry Cullen, Brian A. Jacob, and Steven D. Levitt. All rights reserved. Short sections of text, not to exceed two paragraphs, may be quoted without explicit permission provided that full credit, including (C) notice, is given to the source. 
The Impact of School Choice on Student Outcomes:

An Analysis of the Chicago Public Schools

Julie Berry Cullen, Brian A. Jacob, and Steven D. Levitt

NBER Working Paper No. 7888

September 2000

JEL No. I20, H80, H00

\section{ABSTRACT}

Current education reform proposals involve improving educational outcomes through forms of market-based competition and expanded parental choice. In this paper, we explore the impact of choice through open enrollment within the Chicago Public Schools (CPS). Roughly half of the students within CPS opt out of their assigned high school to attend other neighborhood schools or special career academies and magnet schools. Access to school choice dramatically increases student sorting by ability relative to neighborhood assignment. Students who opt out are more likely to graduate than observationally similar students who remain at their assigned schools. However, with the exception of those attending career academies, the gains appear to be largely spurious - driven by the fact that more motivated students are disproportionately likely to opt out. Students with easy geographical access to a range of schools other than career academies (who presumably have a greater degree of school choice) are no more likely to graduate on average than students in more isolated areas. We find no evidence that this finding can be explained by negative spillovers to those who remain that mask gains to those who travel. Open enrollment apparently benefits those students who take advantage of having access to vocational programs without harming those who do not.

Julie Berry Cullen Department of Economics University of Michigan

Ann Arbor, MI 48109-1220

and NBER

jbcullen@umich.edu

Steven Levitt

Department of Economics

University of Chicago

1126 East $59^{\text {th }}$ Street

Chicago, IL 60637

and NBER

slevitt@midway.uchicago.edu
Brian Jacob

Harris Graduate School of Public Policy

1155 E. $60^{\text {th }}$ Street

Chicago, IL 60637

ba-jacob@uchicago.edu 


\section{Introduction}

The current leading elementary and secondary education reform proposals involve introducing accountability through forms of market-based competition and expanded parental choice. Proponents claim that increased choice will force the current system of local monopolies to become more responsive and efficient. Critics worry that increased choice will isolate the most disadvantaged students in the worst schools and that parents may not be informed enough to make choices in the best interests of their children. ${ }^{1}$ There is a growing body of theoretical and empirical work that presents a mixed picture of the net impact of various forms of choice.

This paper examines public school choice within the Chicago Public School system (hereafter abbreviated CPS). CPS has a number of important features that make it an excellent case for analysis. First, it is the nation's third largest school district, with roughly 400,000 students currently enrolled. Second, parents have an enormous degree of flexibility in choosing which of the more than 60 CPS high schools their child will attend. For the cohorts we examine (those entering $9^{\text {th }}$ grade in the Fall of 1993, 1994, or 1995), there were few restrictions on what school a child could attend within CPS. Third, take-up rates are extremely high relative to other types of choice programs. Roughly half of the students in CPS opt out of the neighborhood school to which they are assigned. Fourth, detailed longitudinal data on student educational outcomes is available for CPS students. Finally, because minority and disadvantaged students are disproportionately represented in Chicago public schools, we are able to explore the impact of choice within an environment about which there is heightened concern.

There are, however, three important weaknesses associated with the Chicago data that limit the scope of the study. The first is that we know very little about student outcomes for those students who leave CPS. In many cases we know their stated reason for leaving the 
system, but we do not observe subsequent educational decisions or performance. Second, even for those students who remain in CPS, the only outcome measures in our data are those directly related to their high school performance: whether a student is enrolled, standardized test scores, and high school graduation. We have no information about labor market outcomes or college attendance. The final and most important limitation of our data set is that we only observe students in a regime where school choice has already been introduced. We do not observe the introduction of open enrollment, which would allow us to gain a better understanding of any general equilibrium effects. For instance, students who previously would have elected to attend private school may instead remain within CPS once school choice is available, or the competition induced by school choice might improve overall school quality. Also, school choice may also have important implications for where a family elects to live, since the schooling and residential decisions are de-coupled when school choice is introduced.

Bearing in mind these important limitations, we analyze three cohorts of students entering public high school in the city of Chicago between 1993 and 1995 - over 60,000 students in total. In spite of the fact that the open enrollment program emerged as part of a desegregation program, we find that school choice has little impact on the degree of racial segregation in Chicago schools compared to a partial equilibrium counterfactual in which all children attend their assigned neighborhood school. School choice, however, leads to dramatically increased sorting by ability. High ability students are much more likely to opt out of their neighborhood schools and virtually all travel involves attending a school with higher-ability peers. In our sample, the cross-school variance in $8^{\text {th }}$ grade math and reading test scores (i.e. test scores prior to entering high school) is four times greater than the hypothetical scenario in which all students attend their neighborhood school.

\footnotetext{
${ }^{1}$ See Chubb and Moe (1990) for a detailed discussion of the pros and cons of choice.
} 
Students who choose to opt out of their assigned neighborhood school are 7.5 percentage points more likely to graduate from high school than peers who are observationally equivalent in $8^{\text {th }}$ grade, off of a baseline graduation rate of 50 percent. $^{2}$ There are several competing explanations for why students who opt out of their assigned school outperform those who stay. If the higher graduation rates among these students are due either to access to higher quality schools or to better student-program matches, then open enrollment confers real benefits. Alternatively, the apparent benefits may be spurious if the better outcomes among travelers reflect either unobserved differences in motivation or negative spillovers to those who are left behind.

We begin our attempt to determine the source of the measured benefit to opting out by examining whether students who have greater access to a wide variety of schools do better on average. We demonstrate that distance to nearby schools is a good predictor of the likelihood a student opts out of the assigned school. ${ }^{3}$ If school choice has real effects on student outcomes, those children who happen to live in areas with many nearby schools should on average derive the greatest benefit from the availability of choice. ${ }^{4}$ Living close to a career academy does increase the probability of graduating, especially for students in the middle of the ability distribution who are most likely to attend career academies. Living near to schools other than career academies, including near to high-achieving schools, is not consistently associated with higher graduation rates.

For schools other than career academies, the finding that students who opt out are more

\footnotetext{
${ }^{2} \mathrm{We}$ focus on graduation rates rather than test scores because of extreme sample selection in the latter (i.e. when a student drops out, we do not observe any further test scores). Even among the quartile of students with the highest test scores in $8^{\text {th }}$ grade, graduation rates are less than 75 percent.

${ }^{3}$ Distance is especially important since no busing is provided. All students must make their own accommodations for getting to and from school.

${ }^{4}$ As we show, the distance to nearby schools appears to be uncorrelated with a student's measured ability, which is critical to our identification strategy.
} 
likely to graduate but that greater access to these schools provides no average benefit is consistent with two stories. Students who opt out to these schools may be better on unobservable dimensions, leading to a spurious positive correlation between travelling and performance. Or, these students may indeed derive benefits from opting out, but at the same time impose negative externalities of an equal magnitude on the students who remain behind. Our analysis suggests that the first scenario has more merit. First, we find that mean peer quality has little influence on graduation rates, calling into question the importance of spillovers. We then examine student outcomes within schools, comparing those who attend because they opt in and those who attend because they were assigned to the school. At high-achieving schools, those who opt in outperform the other students. Presumably, these two groups experience similar peers, resources and teacher quality, so it appears that those who take advantage of choice at these schools systematically differ from other students.

For career academies, in contrast, those who opt in do no better than those who are assigned. This suggests that it is something about the school itself (e.g. teachers, curriculum, etc.), rather than the type of students who select in that accounts for the higher graduation rates. Thus, school fixed effects analyses reinforce that career academies have real effects on students' graduation, though other schools do not. Whatever it is about career academies that improves graduation rates is not captured by traditional measures of school quality, such as teacher-pupil ratios or teacher credentials, which are actually lower than at other schools.

The pattern of results in this study suggests that open enrollment benefits some students in CPS while it does not apparently hurt others. This is true despite very strong associated sorting by ability. And, though we find that travelling improves graduation outcomes for students only if they opt out to career academies, it is important to remember that students who 
travel to other schools may gain other than through improved schooling outcomes, such as through improved safety. ${ }^{5}$

In interpreting our results, the partial equilibrium nature of our analysis cannot be stressed strongly enough. Throughout the paper, we take as our counterfactual a situation in which, absent school choice, the same set of kids would attend CPS and the same set of residential choices would have been made. We also assume that the introduction of increased competitive pressure due to school choice does not affect average school quality. The partial equilibrium analysis introduces two countervailing biases. The effects of school choice we describe above may be overstated if in its absence families would have substituted other strategies for achieving similar educational goals, such as moving to neighborhoods with good schools or taking their children out of CPS entirely. On the other hand, if school choice leads to increased competition and better schools (Hoxby 1994), then our estimates of the impact of school choice understate the true benefits.

The remainder of this paper is structured as follows. Section 2 describes the implementation of the school choice program in the Chicago Public School system and establishes how our study relates to the existing literature on school choice. Section 3 introduces our data set. Section 4 analyzes which students take advantage of school choice and the implications that this has for the composition of schools within CPS. Section 5 estimates the cross-sectional relationship between opting out and graduation rates, while Section 6 explores potential explanations for the observed improved educational outcomes. Section 7 concludes.

\section{Background on School Choice}

\footnotetext{
${ }^{5}$ Peterson et al (1998) find in parent interviews that safety is one of the leading criteria parents consider when choosing whether to participate in the New York City voucher program.
} 


\section{School Choice within the Chicago Public School System}

Over 400,000 students are enrolled in CPS in grades K-12. The district comprises 20 percent of Illinois elementary and secondary enrollment and 1 percent of the national total. With a budget of over $\$ 2.5$ billion in 1995, CPS ranked third nationally among school districts, trailing only New York City and Los Angeles. As in most urban districts, students in the system are disproportionately minority (more than two-thirds) and poverty rates are well above those for the nation as a whole. Given the high rates of disadvantage and poor overall performance relative to national norms, our analysis provides evidence on the net benefits of providing choice to students with otherwise limited opportunities.

CPS introduced public school choice as a part of efforts to achieve racial desegregation. In September 1980, the Chicago Board of Education signed a consent decree with the United States Department of Justice that required the Board to develop a comprehensive desegregation plan to alleviate the effects of historic segregation on Black and Hispanic students. The decree established two primary objectives: (1) to create the greatest number of persistently desegregated schools and (2) to provide compensatory programs to ensure equity of educational outcomes between white and minority students in schools that could not be desegregated. The resulting plan outlined a variety of strategies aimed at meeting these objectives, including the development of magnet schools and magnet programs within neighborhood schools as well as the voluntary transfer of students. These programs are collectively referred to as the "Options for Knowledge Program.”

Prior to the development of the desegregation plan, several high schools were open to students throughout the city, including a school for gifted students (Whitney Young Magnet High School) and several technical high schools. However, the implementation of the 
desegregation plan significantly expanded the system of school choice in Chicago and forms the basis of the system that exists today. Now, students are guaranteed a spot in a pre-assigned neighborhood school, known as the "attendance area" school, determined by a student's place of residence. At the time of our sample, students were also free to apply to any other high school in the Chicago Public School system without limit on the number of concurrent applications. While admissions criteria vary by school, with some requiring written examinations or student interviews, many hold lotteries if they are oversubscribed. The state of Minnesota and individual school districts in more than half of the states have similar programs that allow students to select among public schools.

\section{Previous Literature}

Open enrollment is only one of a variety of initiatives, including private school vouchers, charter schools, and magnet schools, that fall under the umbrella of school choice. While these programs differ in their implications for school financing, the extent to which they involve the private sector, and in scope, they share the goal of breaking the traditional link between neighborhood and schooling. In breaking this link, these programs have the potential to increase the degree of competition faced by local public schools and, thereby, to improve school performance. $^{6}$ From this perspective, school choice can improve all students' opportunities. However, another potential consequence of school choice is increased student sorting. If choice leads to a higher degree of sorting by ability and peer effects matter, then the distribution of educational benefits is likely to be quite unequal (Epple and Romano 1998). The impact of school choice depends on which students take advantage of choice, the types of options that

\footnotetext{
${ }^{6}$ Hoxby (1994) demonstrates that increased Tiebout-style school choice is associated with more efficient public schools.
} 
these students have, and what happens to the students who are left behind.

There is a fairly large body of evidence about the types of students who take advantage of choice. A series of studies of different types of programs, including public and private alternatives, have found that children who participate are both more able and more advantaged (Coleman, Schiller et al. 1993; Witte 1993; Lankford, Lee et al. 1995; Buddin, Cordes et al. 1998; Goldhaber, Brewer et al. 1999). These studies suggest that choice schools increase social class and ability segregation across schools by siphoning off higher achieving and higher income students. Yet, other studies find evidence of participation that is more neutral with respect to background and even skewed toward minorities and low-income families (Duax 1988; Lee, Croninger et al. 1994; Schneider, Schiller et al. 1996).

Evidence on the impact of school choice on the students who participate is also mixed. The Milwaukee voucher program is perhaps the most researched school choice program in the country. Beginning in the Fall of 1990, the Milwaukee public school district offered a limited number of low-income students vouchers to attend one of three private, nonsectarian schools in the district. Voucher recipients were selected from a pool of eligible applicants by a random lottery. Using a variety of methods to identify valid control groups, analyses of this program find anywhere from no achievement gains to large advantages (Witte, Sterr et al. 1995; Green, Peterson et al. 1997; Witte 1997; Rouse 1998). ${ }^{7}$ Public school choice through the presence of magnet schools has been more consistently associated with improved outcomes for students (Blank 1983; Metz 1986; Crain et al. 1992; Gamoran 1996), but the ability of these studies to account for student selection is often more restricted.

\footnotetext{
${ }^{7}$ While in theory randomization provides an ideal context for the evaluation of school choice, in this case the control group was contaminated by selective attrition (Witte 1997). Over half of the unsuccessful applicants never returned to the public schools and those who did return were from less educated, lower income families. More recent studies of publicly and privately funded voucher experiments in other cities that have been more carefully designed from the
} 
An aspect that limits what can be learned from studies of voucher and magnet school programs is that these programs, as they have been implemented, typically affect only a small percentage of students in the district. It is thus difficult to learn anything about either the degree of sorting or the gains and potential spillover effects associated with more systemic choice. ${ }^{8}$ Open enrollment programs provide an opportunity to explore these questions, as well as to revisit the basic questions of whether and why participants benefit. Most of the evidence on the impact of open enrollment is anecdotal or from case studies. An exception, O'Brien and Murdoch (2000), examines a district-wide public school choice program in Texas that, similar to the CPS experience, began with a court desegregation order. While the authors find that academic performance in the choice district is higher than in similar non-choice districts in the state, they do not examine student level achievement data or compare the achievement of those who do and do not opt out of their zone school.

\section{Our Framework}

In this paper, we attempt to shed light on some of the remaining questions about the distribution and source of the benefits of school choice within the context of the CPS open enrollment system. As highlighted in the introduction, our approach is explicitly partial equilibrium. We take the residential decisions, private schooling decisions, and productivity of CPS schools as given. Holding these factors constant, we explore how giving public school students the choice to opt out of their neighborhood school to another public school within the district affects student outcomes.

onset continue to present a wide range of estimated program effects (e.g. Peterson, Myers et al. 1998).

${ }^{8}$ International policy experiments have involved more expansive systems of school choice. However, the lessons are somewhat limited by the lack of individual-level data. For example, New Zealand introduced unrestricted choice among all public and religious schools in 1991. Ladd and Fiske (2000) find that the gap between successful 
Although we do not develop a formal model of school choice, our empirical analysis is motivated by the following set of assumptions. Students differ along both observable dimensions (e.g., past test scores, neighborhood of residence, race, gender, etc.) and unobservable dimensions (e.g., motivation to excel in school and tastes/skills that may interact with school characteristics in the production of educational outcomes). Schools vary according to teacher quality, the composition of peers, and idiosyncratic components that make a particular school more or less attractive to a given student (e.g., the presence of a specialized program). Students maximize utility, of which the educational outcome is just one component. Holding educational outcome constant, students prefer schools that are good matches for them on nonacademic dimensions, and also presumably prefer schools that are closer to home in order to minimize travel costs.

Within such a framework, we would generally, but not categorically, expect students who opt of out local schools to fare better academically for a number of reasons. First, holding student motivation and non-academic components of a student-school match constant, those who opt out of the neighborhood school pay a greater travel cost and thus will be willing to travel only if compensated by an academic benefit. ${ }^{9}$ This academic gain may arise from better teachers, better peers, or a better match. Second, highly motivated students are presumably more likely to opt out of local schools and also likely to do better academically than observationally equivalent students with lower motivation. Thus, even if the link between opting out and attainment is not causal (in the sense that motivation drives both of them), opting out may still be correlated with higher attainment.

and unsuccessful schools has widened since then. However, because the researchers only have access to aggregate data, whether this is due to real effects of choice or to changes in school composition cannot be determined.

${ }^{9}$ It is possible that opting out is associated with lower academic achievement if the primary reasons for attending schools other than neighborhood schools are not academically driven. 
Whether the observed correlation between traveling and outcomes can be explained by unobserved qualities of the students who travel, by improved matches, or through differential peer and school quality has very different implications for the distributional impact of choice. If the link is purely spurious - driven by unobserved differences in motivation - then school choice provides no real benefit. If peer quality is important, then school choice will benefit those who opt out, but hurt those who remain behind. To the extent that school choice leads to better matches between students and schools, then the benefit to those who opt out represent true social gains.

\section{Data Description and Summary Statistics}

In this study, we follow three cohorts of CPS students - those entering $9^{\text {th }}$ grade for the first time in the Fall of 1993, 1994, and 1995 - through their high school years. There are a total of 76,563 students in these cohorts. ${ }^{10}$ Because we condition on $8^{\text {th }}$ grade math and reading achievement scores as proxies for baseline academic performance levels, those students lacking such test scores are dropped from the sample (a total of 6,446 or 8.4 percent of the full sample). Test scores may be missing either because the student was absent the day the test was given, because the student was exempted from the test, or because the student transferred in from a different school district in $9^{\text {th }}$ grade. In addition, 1,089 students are dropped due to other missing data, primarily home address (which we use for the purpose of measuring distance to schools and linking to census-tract-level neighborhood characteristics). Thus, our final sample includes 69,028 students.

We have compiled data from a variety of sources for this analysis. The core data sources

\footnotetext{
${ }^{10}$ This does not include students who attend schools that exclusively serve special needs populations or juvenile detention centers. Those schools operate outside the standard of open enrollment.
} 
are administrative student record and test score files for students in the Chicago Public Schools (CPS). These files provide a complete record of each student's history in CPS, including which schools they attended each semester and records of any standardized test taken starting in first grade. These records include home and school addresses, which allow us to link census data to students and schools, and also to track any residential moves or school transfers. For each high school, we also have data on school capacity, teacher characteristics, financial resources and other school characteristics such as percentage of students receiving free or reduced lunches as well as racial composition of the school. Finally, for a random sub-sample of students in the $19949^{\text {th }}$-grade cohort, we have survey data from their $8^{\text {th }}$ grade that includes questions on family background as well as attitudes toward and experiences in school.

Summary statistics for the students in our sample are presented Table 1. Column 1 includes all students in the sample. Columns 2 and 3 divide the sample into two groups. Column 2 includes all students in our sample who enroll in CPS in $9^{\text {th }}$ grade, but later exit CPS due either to transferring to a private school or moving out of the city of Chicago. Column 3 encompasses all other students - those who graduate from CPS or drop out of school after last attending a CPS school. Because we do not observe subsequent educational outcomes for the roughly 8,000 students in Column 2 who leave CPS sometime after September of their $9^{\text {th }}$ grade to attend school elsewhere, we exclude these students from our individual-level regressions. They are, however, included in the analysis of initial patterns of school choice and in computing average school peer characteristics. The students leaving CPS are primarily moving out of the area, with fewer than 1 out of 5 leaving to attend private schools. They generally appear similar to those who remain with respect to $8^{\text {th }}$ grade test scores, but are more likely to enroll in their assigned school, more likely to be male, and less likely to be Black. 
Columns $4-6$ of the table categorize the students in column 3 by race. More than 60 percent of the entering students are Black and roughly 25 percent are Hispanic. Mean student achievement prior to entering high school, as measured by math and reading achievement ITBS test scores taken in the Spring term of $8^{\text {th }}$ grade, is well below the national average. The national mean test scores (measured in grade equivalents) are 8.8, implying that CPS students on average test more than a grade-level behind the national average. White students test near the national norms. The number of students with standardized test scores falls rapidly in the high school years as a consequence of dropouts. Only half of the students graduate in four years and most others will never graduate.

One reason for the overwhelming minority representation and low achievement for incoming CPS high school attendees is that many Chicago residents elect to send their children to private schools. Based on data from the 1990 Census, the average student who resides in Chicago lives in a tract in which nearly 20 percent of students enrolled in high school attend private schools. Many of the students who attend private high schools also attend private junior high schools. For these students, we have no additional information. We do, however, have information on students who attended CPS in $8^{\text {th }}$ grade, but switched sectors in $9^{\text {th }}$ grade. Students who exit CPS test an average of a grade equivalent higher in $8^{\text {th }}$ grade than those who remain in the Chicago schools. Almost 40 percent of the students who leave are White, compared to only 12 percent of the students who stay.

The middle panel of Table 1 presents Census-tract level characteristics based on student residences. Students in our sample are spread across 814 tracts. White students tend to live in neighborhoods with less poverty, more homeowners, and fewer female-headed households. Living circumstances of Black students, for the most part, are worse than for Hispanics. There is 
a striking degree of racial/ethnic residential segregation. Black students live in tracts that are on average more than 85 percent Black, and White students live in areas that are more than 70 percent White. Hispanics tend to reside in more integrated communities, with the population split about equally between Hispanics and non-Hispanics.

During our sample period, there were 61 regular high schools in CPS system. ${ }^{11}$ Of these schools, 47 are attendance area schools. Students are assigned to one of these 47 schools depending on the student's place of residence. As noted above, this is the default school that a student will attend unless he or she submits an application to attend another school. A student's attendance area school is generally close to his or her house (on average within two miles), but is not necessarily the very closest school. Empirically, for 64 percent of the students in our sample, the attendance area school is the closest school, and for 93 percent of the students it is one of the three closest schools. Some students live closer to career academies or magnet/technical schools that are not assigned to any students as an attendance area school - all students who attend do so by virtue of applying. We refer to these schools as "choice" schools, though students may also apply to attend attendance area schools other than the one assigned to them. Among magnets, three of the schools (Lane, Lindblom, and Young) base admissions on test scores. Enrollment in other schools is not based on test scores. At the time of our sample, there were no geographic restrictions on which school students could attend. ${ }^{12}$

In our analysis, we use an alternative system to classify schools. There is a great deal of variation across choice schools that fall under the rubric of magnet schools, and many attendance area schools also offer magnet programs. And, there are both choice and attendance area schools that are designated as career academies. Therefore, we instead categorize schools into three

\footnotetext{
${ }^{11}$ Since that time, charter schools have opened. At the time of our sample, however, charter schools were not yet operational in Chicago.
} 
mutually exclusive groups: high-achieving, non-high achieving regular/magnet schools, and career academies. High-achieving schools correspond to the top quintile of schools by average $8^{\text {th }}$ grade test scores of the incoming students. The high-achieving schools include all three test schools, most but not all of the magnet schools that are by application only, one career academy that is by application only, and a handful of attendance area schools, most of which are located in affluent areas. The results in the paper are not particularly sensitive to the categorization that we use.

Figure 1 displays a map of Chicago with the location of each public high school, the category to which it is assigned, and median incomes by neighborhood. A number of points are worth highlighting in the map. First, schools are not located uniformly across the city. In some areas, a number of schools are clumped close together, whereas other schools are relatively geographically isolated. This dispersion of schools is important to the strategy we employ to determine the net benefits of choice. Second, while high-achieving schools tend to be in wealthy neighborhoods, there appears to have been a conscious effort on the part of the Chicago School Board to locate choice schools in areas with high proportions of poor and minority students as part of the desegregation project. Finally, note that the three test-based schools (Lane, Lindblom, and Young) are located so as to make at least one of them accessible from all parts of the city.

The bottom panel of Table 1 presents attendance patterns by school type. Overall, less than half of all students actually enroll in their assigned attendance area school. Thus, in contrast to previous studies of school choice in which take-up rates for students are quite low, in Chicago there is an enormous amount of student reallocation due to school choice. The students who opt out of their assigned school are split about equally between high-achieving schools, lowachieving schools, and career academies. There are stark racial differences in the patterns of

\footnotetext{
${ }^{12}$ The system has changed to have zones of eligibility since then.
} 
school choice. Although White and Black students opt out of their local schools with similar frequencies, Whites are much more likely to travel to attend high-achieving schools than Blacks (41.1 percent vs. 12.3 percent of all students). These ratios are reversed for career academies. Hispanics are substantially less likely to opt out of their local schools; when they do, their attendance patterns are generally intermediate between Whites and Blacks.

Table 2 further explores the characteristics of Chicago schools by type of school. Average $8^{\text {th }}$ grade test scores are by definition highest at high-achieving schools, over one grade equivalent higher than at career academies and other schools and approximately at national norms. Living circumstances, as measured by either living with at least one parent or by a blockgroup level measure of social status (higher numbers imply better living conditions), are also better for students attending high-achieving schools. Finally, students tend to travel further to attend these schools. Career academies and other lower-achieving schools are not very different according to family background and peer quality measures, though career academies are disproportionately Black.

\section{The Impact of School Choice on the Allocation of Students across Schools}

Because high ability students are more likely to opt out of local schools, school choice substantially changes the peer group with which a student of a given ability level can expect to interact. Figure 2 plots the predicted peer group achievement level (based on average $8^{\text {th }}$ grade math test scores) as a function of a student's $8^{\text {th }}$ grade math test score under two different scenarios. The first scenario is the actual distribution of students under the current school choice plan. The second scenario assumes that all students attend their assigned local school, representing the counterfactual distribution in the absence of choice. In order to compare sorting 
by ability across these two scenarios, we parameterize the relationship between a student's own achievement and peer achievement under each scenario. We run a regression of the average peer $8^{\text {th }}$ grade math score among $9^{\text {th }}$ grade peers in either the school the student attends or the assigned school on a quartic in the student's $8^{\text {th }}$ grade math test score. ${ }^{13}$ If there were perfect sorting on ability, then the empirical distribution would mirror the 45-degree line.

In Figure 2, without choice there is an extremely weak and virtually linear relationship between a student's own test scores and the set of peers he or she expects to interact with. A student performing at the $4^{\text {th }}$ grade level would expect to attend a school with average test scores only about one-fourth of a grade equivalent lower than a student performing at the $10^{\text {th }}$ grade level. There is much more sorting based on ability with school choice, particularly for highachieving students. Students with test scores below the $8^{\text {th }}$ grade level on average attend schools with lower performing peers under school choice. The very highest performing students are segregated in schools with average test scores more than a grade-equivalent higher than would have been expected without school choice. To the extent that there are positive peer effects, high ability students gain with school choice whereas low ability students may be hurt, a topic to which we return in Section 6.

Table 3 provides alternative views of sorting due to school choice. In each instance, we compare a hypothetical counterfactual in which all students attend their assigned school to the actual attendance patterns. We also present results excluding the three test-based magnet schools to provide a sense of how much of the sorting is due to the concentration of the brightest students in these schools.

The top panel of the table reports the total variance in student test scores within-school

\footnotetext{
${ }^{13}$ Note that this analysis is based on $8^{\text {th }}$ grade test scores, i.e. the year preceding high school. Thus, we do not have to be concerned about reverse causality.
} 
and between-school. Within-school variance falls by approximately 25 percent with school choice, revealing that students within a school are more similar after school choice than before. The between-school variance, on the other hand, nearly quadruples if the three test-based magnets are included, and more than doubles even when those schools are excluded.

Another means of representing the impact of school choice on ability-based sorting is presented in the middle panel of Table 3. CPS schools in which less than 15 percent of students demonstrate achievement at or above the national average are subject to probationary measures. ${ }^{14}$ Under the current system, 39.5 percent of the high schools have incoming student bodies that meet this criterion in math; for reading the parallel figure is 57.9 percent. If every student attended his or her assigned school, the fraction of schools above this threshold would rise to 65.6 percent for math and, remarkably, 95.7 percent for reading.

One of the original and still frequently stated objectives of school choice, and an explicit component of the CPS school choice program, is to achieve racially integrated schools. In Chicago, however, there is little evidence that school choice contributes to this goal. If all students attended their assigned schools, 47.9 percent of students would attend a school that was either at least 85 percent Black or 85 percent Hispanic. ${ }^{15}$ With school choice, the figure is actually higher -49.0 percent. If one includes schools that have a combined Black and Hispanic population of 85 percent, the fractions are 69.1 percent without school choice and 67.5 percent with school choice. When a more stringent definition of integration is used - less than 70 percent Black and Hispanic - the percentage of students in integrated schools increases from 16.1 percent without school choice to 20.0 percent with school choice. Thus, the evidence on the

\footnotetext{
${ }^{14}$ Probation was instituted in the CPS in the 1996-97 school year and in 1999-2000 the standard was raised to 20 percent of students at or above national norms.

${ }^{15}$ We use the cutoff values of 85 percent and 70 percent because these are ranges employed by CPS itself in determining the extent to which a school is segregated.
} 
impact of school choice on sorting by race is mixed.

An important caveat to these findings is the partial equilibrium nature of our counterfactual. Introducing within-district choice in Chicago may have encouraged high ability students to remain in the public sector and/or have reduced the degree of residential sorting relative to a system with residence-based attendance. Therefore, the degree of sorting in the absence of choice may be understated.

\section{The Academic Benefit Associated with Opting Out of the Assigned School}

In this section, we quantify the relationship between opting out and attainment. We focus our analysis exclusively on attainment, even though we do have achievement measures such as test scores available to us. Our rationale for doing so is the extreme sample selection that arises due to high dropout rates. ${ }^{16}$ We begin with linear probability models based on the full sample and a single measure for opting out, and then investigate the extent to which the benefits of opting out vary along observable dimensions. We do not attempt to determine the underlying reasons for the higher relative outcomes for travelers in this section, instead deferring that discussion to the next section.

The basic estimates of the effect of opting out on student educational attainment are presented in Table 4. The specifications reported are from ordinary least squares regressions; probit models yield similar results evaluated at the mean. Standard errors, corrected for heteroskedasticity due to clustering by Census tract, are in parentheses.

\footnotetext{
${ }^{16}$ In our initial analysis of test score data, we found the results to be quite sensitive to different sample selection corrections. Especially problematic is the fact that, controlling for prior test scores and other observable student characteristics, traveling is positively associated with remaining in school and, by default, taking the exams. Thus, students who take advantage of choice are more likely to take the exams than observably similar students who attend their assigned school. If students who learn less in school are those who are more likely not to take the exams, as seems likely, travelers will appear to learn less than they actually do relative to non-travelers due to differential testtaking.
} 
The top row of the table presents the coefficients associated with an indicator variable for whether a student opts out of his or her assigned school. Controlling for a wide range of other observables - most importantly the student's own test scores in $8^{\text {th }}$ grade - opting out is associated with close to an 8 percentage point increase in completion of $10^{\text {th }}$ grade, $11^{\text {th }}$ grade, and graduation on time. ${ }^{17}$ The results imply that all of the effect of traveling on attainment occurs by $11^{\text {th }}$ grade, i.e., conditional on completing $11^{\text {th }}$ grade, opting out is not associated with higher graduation rates. All of these estimates are highly statistically significant. Compared to other educational interventions in the literature, opting out is associated with a large increase in years of schooling.

The other variables in the regressions are also of interest. Test scores from $8^{\text {th }}$ grade are extremely good predictors of later attainment. Controlling for other factors, males are less likely to graduate than females. There are relatively small differences in graduation rates across races. There is some evidence of positive effects of living with at least one parent and living in a neighborhood with higher socio-economic status. Moving between census tracts in the year prior to $9^{\text {th }}$ grade is associated with lower graduation rates. Students assigned to special education in $8^{\text {th }}$ grade, controlling for other factors including $8^{\text {th }}$ grade achievement are more likely to graduate. Note that the inclusion of the wide range of covariates slightly increases the coefficient on opting out relative to the model that includes only $8^{\text {th }}$ grade test scores. ${ }^{18}$

Table 5 analyzes cross-sectional variation in the measured value of opting out. The top two panels stratify the sample according to observable student characteristics. Dividing students

\footnotetext{
${ }^{17}$ In our sample, 75.2 percent of students complete $10^{\text {th }}$ grade, 59.9 percent complete $11^{\text {th }}$ grade, and 50.3 percent graduate on time.

${ }^{18}$ In our specifications in Table $4,8^{\text {th }}$ grade test scores are constrained to affect attainment in a linear fashion. Given the importance of these variables, we have thoroughly investigated the relationship between past test scores and future attainment. Including four-part splines in both $8^{\text {th }}$ grade math and reading scores to allow for non-linearity in the impact of lagged test scores has little impact. Adding $7^{\text {th }}$ grade test scores, either linearly or in a four-part spline, also has little impact on the coefficient for opting out.
} 
by quartile based on their combined $8^{\text {th }}$ grade math and reading scores reveals little systematic difference across the attainment measures. Categorizing students by race, Hispanic students obtain somewhat smaller attainment gains.

The next three panels explore how the benefits to opting out vary by the types of choices that travelers make. Grouping students according to average $8^{\text {th }}$ grade test score in the school that they attend relative to their assigned school yields striking results. Those students who attend schools in which the peers have combined math and reading test scores that are two grade equivalents higher than the school the student was originally assigned to gain the most. The impact of travel on all of the attainment measures declines monotonically with the relative quality of peers. Even those students who opt to attend schools with lower-achieving peers than the school they were assigned to have positive (but statistically insignificant) effects of traveling. Of the three school types, opting out to a high-achieving school is associated with the greatest gains. Career academies have coefficients about half as large, while other schools yield the lowest benefits. Finally, there is little relationship between the distance traveled and gain in attainment. While this finding suggests students are not compensated for incurring higher travel costs, the patterns of measured effects across types of travel are consistent with real benefits from opting out of neighborhood schools to "better" schools.

\section{Disentangling the Reasons Why Students who Opt Out Perform Better}

Having established a link between opting out of the assigned school and higher educational attainment and test scores, we turn our attention to trying to understand the source of those gains. We focus on four main hypotheses as to why travelers might do better: (1) they are more motivated, (2) they are on average traveling to "better" schools, (3) by traveling they find a 
school which better matches their educational needs for idiosyncratic reasons, or (4) by opting out of their neighborhood school, they impose a negative externality on those who remain behind. Regarding (4), the coefficients in the OLS regression capture the gap between the performance of two observationally similar students, one who travels and one who does not. If school choice hurts those who do not travel, then the gains to travelers will be exaggerated Ideally, we would like to adopt an empirical strategy that neatly parses the impact of traveling into these various categories. In practice, what we are able to do is far cruder because of the role of unobservables like motivation and match quality. Our approach is as follows. We begin by analyzing whether students on average benefit from greater access to school choice (as reflected in shorter distances to schools other than their assigned school). Under the assumption that student motivation is uncorrelated with these distance measures, this approach will purge the estimates of any influence of motivation. These estimates, however, measure the net benefit to students in areas with more choice, and thus incorporate any negative externalities as well as any direct benefits. We test for negative externalities by looking for a relationship between predicted peer quality and individual attainment. We provide complementary evidence by analyzing whether the performance of students who opt into a school systematically differs from the performance of students who are assigned to that same school. These two sets of students experience similar peers and school resources. Thus, to the extent that peers or resources are important determinants of educational outcomes, looking within schools should reduce the measured benefit of travel.

\section{Do Students Benefit on Average From Greater Access to School Choice?}

If it is the case that school choice provides real benefits to students, then it seems 
plausible that those students with the greatest access to a wide range of schools should benefit the most. Although technically any student could attend any school, in practice there are important travel costs associated with attending schools far from home. This is especially true since each student must provide his or her own transportation to and from school. As a consequence, distance to other schools is an important factor in determining the school in which a student enrolls.

To provide intuition for the type of experiment that we have in mind, Figure 3 depicts two similar attendance area schools surrounded by very different patterns of outside opportunities. Students assigned to the Hyde Park Career Academy have fewer, more distant, and less attractive neighboring schools than students at Robeson. Both schools are very similar demographically and are equally low-performing. However, students assigned to Robeson are nearly 4 times as likely to opt out. ${ }^{19}$

The top panel of Table 6 demonstrates the importance of distance in the decision to opt out in a regression context, controlling for the full set of covariates utilized in the earlier tables. The specifications include four separate distance measures corresponding to the log distance from the centroid of a student's census tract to the assigned school, the nearest career academy, the nearest high-achieving school, and the nearest school that does not fall into either of these categories. ${ }^{20}$ Unlike the other distance measures, distance to one's own attendance area school cannot be interpreted as an indicator of the degree of choice. Given its empirical importance -

\footnotetext{
${ }^{19}$ Allensworth and Rosenkranz (2000) examined access to magnet schools in Chicago. Based on geographic clustering, they concluded that certain students have considerably greater access to magnet schools than others. For example, roughly half of the students in the CPS do not live within a 1.5 mile radius of any magnet elementary school. They also found that magnet high schools are located in economically diverse areas of the cities.

${ }^{20}$ Distance from the census-tract centroid to the schools is a proxy for the distance from the student's house to the schools. Because of our sample size and the large number of CPS schools, geocoding individual addresses proved infeasible. Census tracts in Chicago average .23 square miles and the distance from a typical student's house to the tract centroid is less than .20 . For a student who lives on the edge of a census-tract, the distance to the centroid is rarely more than .50 miles.
} 
distance from one's assigned school is highly positively related to the likelihood of opting out we use this distance later to help predict peer quality. We include it here to be consistent, though we do not focus on it in the discussion.

The impact of the distance variables on opting out vary substantially across the ability distribution, so we present separate estimates by $8^{\text {th }}$-grade test score quartile, as well as overall estimates constraining students from all quartiles to have the same parameters. The coefficient on $\log$ distance to the nearest career academy is negative for all ability quartiles, but has the greatest impact on students in the middle quartiles. This result is consistent with the fact that students in these quartiles are most likely to attend career academies. Access to high-achieving schools does not have a statistically significant impact on the behavior of low-ability students, but has a substantial impact on the highest achievers. For the highest-quartile children, distance to high-achieving schools is the most important of the three distance measures. Distance to other nearby schools that are neither career academies nor high-achieving has the biggest impact on students at the bottom of the ability distribution, again consistent with actual travel patterns.

If these distance measures are as good as randomly assigned, conditional on other observable characteristics, then the distances can be used to evaluate whether greater access to school choice provides educational benefits. The primary concern is that the distance measures may be correlated with unobserved measures of ability or motivation. ${ }^{21}$ While there is no direct test of the relationship between distance and these unobservables, it is possible to test for a correlation between distance and observed measures of lagged ability, namely $8^{\text {th }}$ grade test scores. These results are shown in Table 7. The four columns of the table correspond to the different distance measures used in the analysis. In addition to $8^{\text {th }}$ grade test scores, all of the

\footnotetext{
${ }^{21}$ For instance, families that care the most about education may choose to reside in an area with many nearby schools.
} 
other covariates included in the earlier regressions are included. In none of the cases can the null hypothesis that the test score variables are jointly insignificant be rejected at the .05 level. Thus, there does not appear to be a systematic relationship between observable measures of ability and the distance measures, increasing our confidence that the distance measures are as good as randomly assigned. ${ }^{22}$ If this is the case, then our estimates of the impact of increased choice on future school outcomes will not be contaminated by bias due to unobserved factors such as motivation - unlike the estimates of the value of opting out from the previous section.

The impact of distance on graduation probabilities is presented in the bottom panel of Table 6. In addition to the distance measures reported in the table, these regressions include the full set of covariates. If greater access to school choice (proxied by shorter travel distance) benefits students on average, then the coefficients on the last three distance measures in this panel should be negative. The strongest results emerge for career academies, where for each quartile of the ability distribution, being farther away from the nearest career academy reduces the likelihood of graduation. The largest effects are in the middle of the ability distribution, consistent with the earlier finding that these students are most likely to opt out to career academies. Based on the estimates in Table 6 , a student between the $25^{\text {th }}$ and $50^{\text {th }}$ percentiles of the ability distribution who lives 2 miles closer to a career academy (roughly one standard deviation) will be 2.1 percentage points - about 5 percent - more likely to graduate high school than a comparable peer.

Surprisingly, proximity to high-achieving schools provides no apparent benefit to students in the highest ability quartile - the students most likely to opt out to attend such schools.

\footnotetext{
${ }^{22}$ As further evidence on this point, we relied on reports of expectations provided by students who participated in a survey administered to one of the cohorts in our data set in $8^{\text {th }}$ grade. Adding an indicator for a student believing that he or she is likely to graduate high school reveals no significant relationship between this variable and the distance measures.
} 
This is in stark contrast to the baseline results, which implied that going to a high-achieving school had an enormous (15 percentage point) impact on graduation. These conflicting results are consistent with students who choose to attend high-achieving schools being systematically different from observationally equivalent students who do not select (or are not selected by) such schools.

The distance to schools that are neither career academies nor high-achieving has no systematic impact on graduation rates. Thus, the results in Table 6 confirm an important effect of access to career academies on graduation, but provide little convincing evidence for other types of schools.

\section{Do Students Who Opt Out Impose Negative Externalities on Those Who Remain Behind?}

The results of Table 6 above tell us only whether closer proximity to schools other than the neighborhood school help students on average. It is possible, however, that some students are helped by access to choice and others are made worse off. This would mean that the findings of no apparent benefit for schools other than vocational schools may actually mask real benefits to those who opt out offset by losses to those who stay at neighborhood schools. The standard story is one in which those who remain behind are hurt by the exodus of top students.

The results for high-achieving schools from Table 6 provide some insight into this question. Most of the students opting out to attend high-achieving schools are in the top ability quartile. As discussed above, there is little evidence that such students benefit from greater access to high-achieving schools. Note, however, that students in the bottom three ability quartiles appear to do somewhat better when high-achieving schools are nearby, even though they are unlikely to themselves attend such schools. 
To further explore the potential distributional consequences operating through peer effects, we add average peer quality (as proxied by $8^{\text {th }}$ grade combined math and reading test scores) to the regressions. ${ }^{23}$ Actual peer quality at the school a student attends, however, is likely to be endogenous. It reflects the student's decision to either attend or opt out of the assigned school, and if the student opts out, the decision of which of the 61 high schools to attend. Therefore, we also predict peer quality for each student.

For each student, the probability of staying at the attendance area school and the probability of opting out to each category of school (e.g. high-achieving) are estimated using specifications similar to those in the top panel of Table 6. Expected peer quality is predicted as a weighted average of quality at the attendance area school, nearest high-achieving school, career academy, and other school, with the weights corresponding to these probabilities. As a further safeguard against endogeneity, rather than using actual quality at the attendance area school in this calculation, we generate a predicted value for attendance area peer quality based on the probability that each child assigned to that school actually attends. Our predicted measure for expected peer quality is highly correlated with the peer quality that a student actually experiences $(\rho=0.61)$, but does not depend at all on a student's actual choice of schools.

Table 8 presents OLS estimates of the impact of actual and predicted peer quality on graduation rates. Actual peer quality appears to have a significant positive impact on graduation rates, as is typically found in the literature. A one grade-level equivalent increase in average peer combined test scores is associated with a 2-3 percentage point increase in graduation likelihood. For purposes of comparison, a one grade-level equivalent increase in a student's own $8^{\text {th }}$ grade test scores (included in the regression, but not shown in the table), is associated with

\footnotetext{
${ }^{23}$ We have experimented with more complicated approaches to modeling peer effects, e.g. including average test scores by quartile of the ability distribution at a school. These alternative approaches yield similar conclusions.
} 
roughly a 9 percentage point increase in the probability of graduation.

The importance of peer effects changes dramatically, however, when predicted peer quality is included instead in the bottom half of Table 8 . The benefit of having good peers disappears once the estimates are purged of endogeneity, mirroring the findings of Jencks and Mayer (1990) and Evans, Oates et al. (1992). There is no evidence of a causal link between peers with high prior achievement and graduation rates. In fact, the point estimates on peer ability become (insignificantly) negative for all quartiles of the ability distribution. Consequently, there appears to be little cause for concern that the availability of school choice imposes substantial costs in terms of the attainment of students who remain at their neighborhood school.

Additional Evidence on Why Opting Out Improves Attainment from Within-School Estimates

Of the 61 schools in CPS, 47 are attendance area schools, meaning that some students are assigned to them. Other students, however, are allowed to opt into these schools. As a consequence, for this subset of schools, we are able to identify the impact of traveling to the school controlling for school-fixed effects. ${ }^{24}$ Within a school, students are likely to experience similar average peer quality, teacher quality, resource levels, and curriculum. Thus, if any of those factors are important in determining why those who opt out are more likely to graduate, adding school-fixed effects should diminish the estimated impact on graduation rates. On the other hand, if adding school dummies has little impact on the travel coefficient, then other explanations such as unobserved motivation or better match quality for those who travel must explain the cross-sectional relationship.

\footnotetext{
${ }^{24}$ For the 14 schools in which enrollment is by application only, all students who attend must by definition travel, so there is no within-school variation in the opting out variable.
} 
The first column of Table 9 simply reports baseline OLS estimates of the impact of opting out to the three types of schools from Table 5. The second column of the table reports the results from the exact same regression, but restricts the sample to students who attend one of the 47 attendance area schools, since this is the sample that implicitly identifies the within-school estimates. The results obtained in the sub-sample are similar to those of the overall sample. Column 3 adds school-fixed effects to the regression on the full sample. For career academies, the coefficient shrinks by 80 percent compared to what was found for the attendance area sample and is no longer statistically significant. The graduation benefits of attending career academies seem to accrue to all students - those who attend via choice and those who attend by default because they are assigned to the school. These findings are consistent with the special curricula in career academies helping to keep students in school.

For high-achieving schools and schools that are neither high-achieving nor career academies, the results are very different. Adding school-fixed effects has little impact on the measured benefit of opting out. This suggests that the higher graduation rates among students opting out to those types of schools is unlikely to be due to peers, resources, teachers, or curriculum at those schools. Instead, consistent with the earlier findings, the apparent benefit to students opting out to attend such schools is likely to be spuriously driven by unobserved characteristics of these students.

One critique of the above interpretation is that many attendance area schools feature magnet programs. One might expect that travelers disproportionately take advantage of such programs. If that were the case, a single fixed-effect per school may not capture the range of experiences of students at the school. The inclusion of school and ability quartile interactions to more closely capture shared school experiences in column 4, however, reduces the estimates 
only slightly.

\section{Conclusion}

The Chicago Public Schools have implemented a system of school choice in which more than half of all students elect to opt out of their local assigned school to attend another public school in Chicago. The immediate impact of the school choice system is to dramatically increase the degree of segregation by student ability. Although students who opt out are more likely to graduate than observationally equivalent students who attend their neighborhood school, our evidence suggests that the primary explanation for this correlation is that those who opt out are superior along unobservable dimensions such as their motivation level. The exception to this finding is career academies, which appear to provide real improvement in graduation rates. We also find no evidence of negative spillovers to those students who are left behind. Our results provide little ammunition for those holding extreme views in favor of or against school choice. With the exception of career academies, there seem to be few apparent benefits of school choice (at least in the partial equilibrium setting in which we examine the question), but nor are there any obvious externalities imposed on students who do not exercise their choice.

Perhaps the greatest puzzle raised by our analysis is why so many students choose to opt out of their assigned school, despite the fact that we are able to identify little tangible academic benefit of doing so. One possible explanation is that there are non-academic reasons for opting out. Most students who leave their local school attend a school with more academically talented peers who come from neighborhoods with higher socio-economic characteristics. It is possible that such schools have lower levels of violence, for instance. ${ }^{25}$ Alternatively, it may simply be

\footnotetext{
${ }^{25}$ Nonetheless, if this were the case, one might predict that students attending such schools would be more likely to graduate. Yet, we do not find this.
} 
the case that students and their parents do not accurately gauge the education production function. Students and parents have little information about educational inputs (e.g., the raw ability of students attending a particular school), but good information about educational outputs (e.g., average test scores and graduation rates). Given this limited information, it may be rational to opt out of local schools to attend schools with higher levels of outputs, even though in reality, the latter set of schools on average confer no additional benefits to those who attend. 


\section{References}

Allensworth, E. M. and T. Rosenkranz (2000). Access to Magnet Schools in Chicago. Chicago, I.L., Consortium on Chicago School Research.

Blank, R. K. (1983). Survey of Magnet Schools: Analyzing a Model of Quality Integrated Education. Washington, DC, ABT Associates for the Department of Education.

Buddin, R. J., J. J. Cordes, et al. (1998). "School Choice in California: Who Chooses Private Schools." Journal of Urban Economics 44: 110-134.

Chubb, J. E. and T. M. Moe (1990). Politics, Markets and America's Schools. Washington, DC, Brookings Institution.

Coleman, J., K. Schiller, et al. (1993). Parent Choice and Inequality. Parents, Their Children and Schools. B. Schneider and J. Coleman. Boulder, CO, Westview Press: 147-182.

Crain, R.L, A.L. Heebner, et al. (1992). The Effectiveness of New York City's Career Magnet Schools: An Evaluation of Ninth-Grade Performance Using an Experimental Design. Berkeley, CA, National Center for Research in Vocational Education.

Duax, T. (1988). The Impact of Magnet Schools on a Predominantly Black Community. Madison, University of Wisconsin, Madison.

Epple, D. and R. E. Romano (1998). “Competition Between Private adn Public Schools, Vouchers and Peer-Group Effects.” American Economic Review 88(1): 33-62.

Evans, W. N., W. E. Oates, et al. (1992). "Measuring Peer Effects: A Study of Teenage Behavior.” The Journal of Political Economy 100(5): 966-991.

Gamoran, A. (1996). "Student Achievement in Public Magnet, Public Comprehensive, and Private City High Schools." Educational Evaluation and Policy Analysis 18 (1):1-18. 
Goldhaber, D. D., D. J. Brewer, et al. (1999). “Testing for Sample Selection in the Milwaukee School Choice Experiment.” Economics of Education Review 18(2): 259-67.

Green, J. P., P. E. Peterson, et al. (1997). The Effectiveness of School Choice: The Milwaukee Experiment. Cambridge, MA, Program on Education Policy and Governance, Harvard University.

Hoxby, C. M. (1994). Does Competition Among Public Schools Benefit Students and Taxpayers? Cambridge, MA, National Bureau of Economic Research.

Jencks, C. and S. E. Mayer (1990). The Social Consequences of Growing Up in a Poor Neighborhood. Inner-City Poverty in the United States. L. E. Lynn and M. G. H. McGeary. Washington, DC, National Academy Press: 111-186.

Ladd, H. F. and E. B. Fiske (2000). When Schools Compete: A Cautionary Tale. Washington, D.C., Brookings Institution Press.

Lankford, R. H., E. S. Lee, et al. (1995). “An Analysis of Elementary and Secondary School Choice." Journal of Urban Economics 38: 236-251.

Lee, V. E., R. G. Croninger, et al. (1994). "Parental Choice of Schools and Social Stratification." Educational Evaluation and Policy Analysis 16: 434-457.

Metz, M. H. (1986). Different by Design: The Context and Character of Three Magnet Schools. New York, Routledge Press.

O'Brien, D. M. and J. C. Murdoch (2000). School Choice in a Large Texas School District. American Education Finance Association Annual Meeting, Austin, Texas.

Peterson, P. E., D. Myers, et al. (1998). An Evaluation of the New York City School Choice Scholarship Program: The First Year. Cambridge, MA, Mathematica Policy Research and the Harvard Program on Education Policy and Governance. 
Rouse, C. E. (1998). "Private School Vouchers and Student Achievement: An Evaluation of the Milwaukee Parental Choice Program." Quarterly Journal of Economics 113(2): 553-602.

Schneider, B., K. S. Schiller, et al. (1996). "Public School Choice: Some Evidence from the National Education Longitudinal Study of 1988." Educational Evaluation and Policy Analysis 18(1): 19-29.

Witte, J. F. (1993). The Milwaukee Private-School Parental Choice Program. School Choice: Examining the Evidence. E. Rasell and R. Rothstein. Washington, DC, Economic Policy Institute: $69-110$.

Witte, J. F. (1997). Achievement Effects of the Milwaukee Voucher Program. American Economics Association Annual Meeting, New Orleans.

Witte, J. F., T. D. Sterr, et al. (1995). Fifth-Year Report: Milwaukee Parental Choice Program. Madison, Wisconsin, University of Wisconsin. 


\section{Data Appendix}

\begin{tabular}{|c|c|c|}
\hline Data & Source & Construction \\
\hline Student Outcomes & CPS Board & $\begin{array}{l}\text { Standardized test scores are taken directly from student test } \\
\text { and transcript files provided by the Board. Information on } \\
\text { graduation is from administrative records provided by the } \\
\text { Board. We classify a student as having graduated if the } \\
\text { student is not actively enrolled in the CPS in the Fall } \\
\text { following their fourth year of high school and the reason the } \\
\text { student left the CPS is marked as graduation. }\end{array}$ \\
\hline $\begin{array}{l}\text { Attendance Area } \\
\text { School }\end{array}$ & CPS Board & $\begin{array}{l}\text { Board staff matched students to attendance area schools using } \\
\text { students' Fall } 9^{\text {th }} \text { grade addresses and current (Fall 1999) } \\
\text { attendance area boundaries provided by the CPS. A few } 1999 \\
\text { attendance area schools did not exist as options for our 1993- } \\
95 \text { cohorts. In these cases, we assume that the attendance area } \\
\text { school is the closest neighborhood school that is attended by } \\
\text { the majority of affected students in our cohorts. }\end{array}$ \\
\hline $\begin{array}{l}\text { Distance } \\
\text { Variables }\end{array}$ & CPS Board & $\begin{array}{l}\text { Student and school addresses were geocoded using MapInfo } \\
\text { software. We approximate home-to-school distances as the } \\
\text { distance from the centroid of the census tract in which the } \\
\text { student lives to the centroid of the tract in which the particular } \\
\text { school is located. }\end{array}$ \\
\hline $\begin{array}{l}\text { Student } \\
\text { Demographics }\end{array}$ & CPS Board & $\begin{array}{l}\text { Student demographic variables (race, gender, age) come } \\
\text { directly from student records provided by the Board. Family } \\
\text { composition is based on information indicating the child's } \\
\text { guardian in the Fall of } 9^{\text {th }} \text { grade. Special education status } \\
\text { covers a variety of disabilities ranging from mild learning } \\
\text { disabilities to severe physical handicaps. }\end{array}$ \\
\hline Student SES & $\begin{array}{l}1990 \\
\text { Census }\end{array}$ & $\begin{array}{l}\text { We created a measure of social status using } 1990 \text { Census } \\
\text { measures at the student block group level. The index } \\
\text { combines information on the percent of employed residents } \\
\text { who are professionals and the mean education level of } \\
\text { residents in the student's block group in the Fall of } 9^{\text {th }} \text { grade. }\end{array}$ \\
\hline $\begin{array}{l}\text { Neighborhood } \\
\text { Characteristics }\end{array}$ & $\begin{array}{l}1990 \\
\text { Census \& } \\
\text { CPS Board } \\
\& \text { CCSR }\end{array}$ & $\begin{array}{l}\text { Basic information on the student's census tract, such as } \\
\text { median household income and percent below the poverty line, } \\
\text { comes from the } 1990 \text { Census. The crime composite is an } \\
\text { index created by factor analysis using official crime statistics } \\
\text { for } 1994 \text { provided by the Consortium on Chicago School } \\
\text { Research (CCSR). The index was created at the block group } \\
\text { level. The variable used in this analysis is a tract-level } \\
\text { average (for the student's tract in the Fall of } 9^{\text {th }} \text { grade), } \\
\text { weighted by the total population in each block group. }\end{array}$ \\
\hline School Resources & CPS Board & $\begin{array}{l}\text { Information on the characteristics of the full time teaching } \\
\text { staff comes from administrative personnel files for the 1996- } \\
97 \text { school year. School finance variables are from CPS } \\
\text { budget data for the } 1994-95 \text { school year. }\end{array}$ \\
\hline
\end{tabular}


Figure 1: Geographic Distribution of CPS High Schools

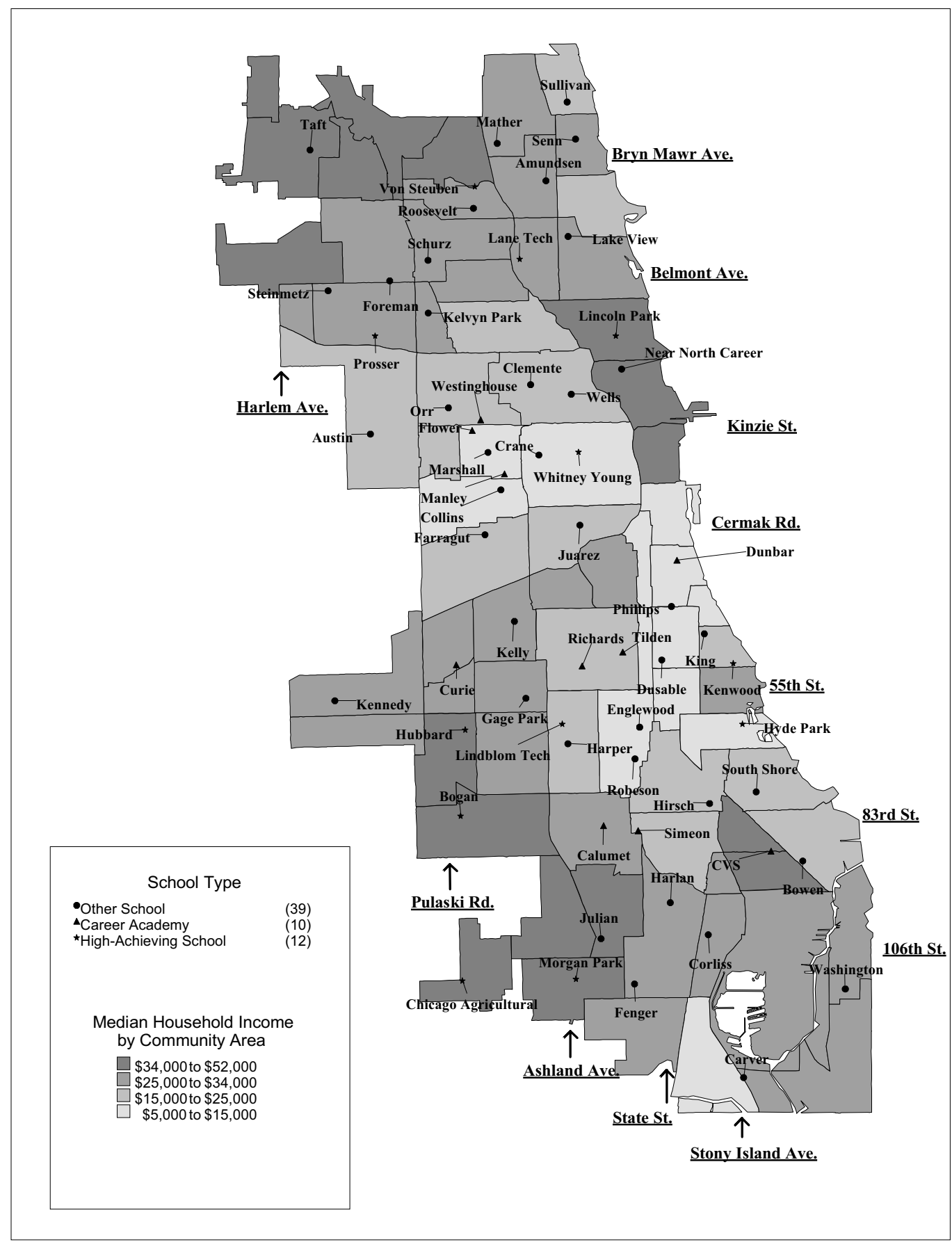


Figure 2: Impact of Choice on Sorting by Ability

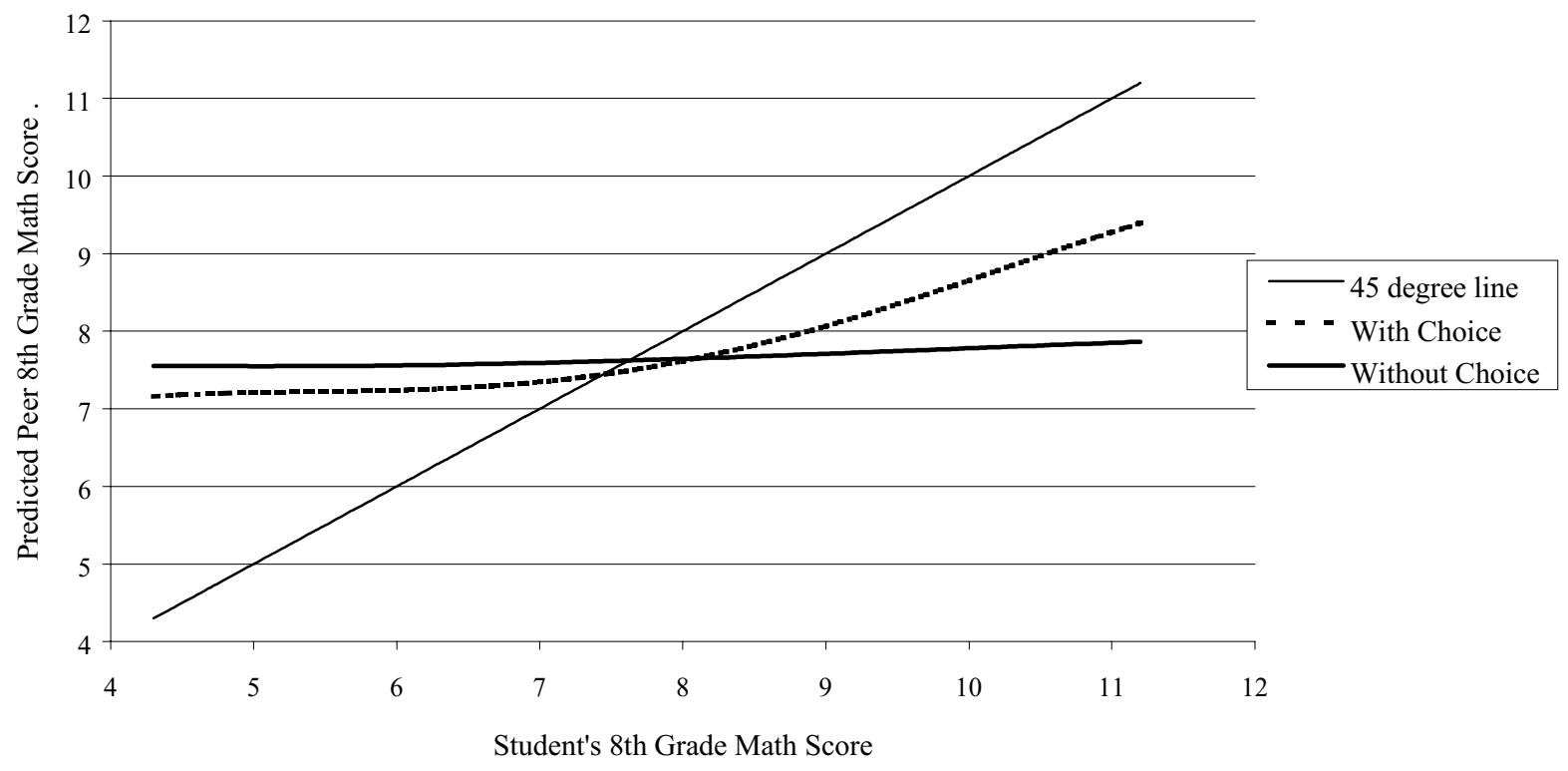

Notes to Figure 2: Individual students' 8th grade math scores are depicted on the x-axis. We predict the expected average 8th grade math score of a student's 9th grade peers given actual attendance patterns (with choice) and under the assumption that all students attend their assigned school (without choice). Average peer score is predicted by regressing the mean score within a student's school under the alternative assumptions on a quartic in the student's 8th grade score. The sample is the full sample of students enrolled in 9th grade in the Fall of 1993, 1994 , or 1995 who took the 8 th grade achievement exams in the prior Spring. The national norm is 8.8 
Figure 3: Patterns of School Choice (An Example)

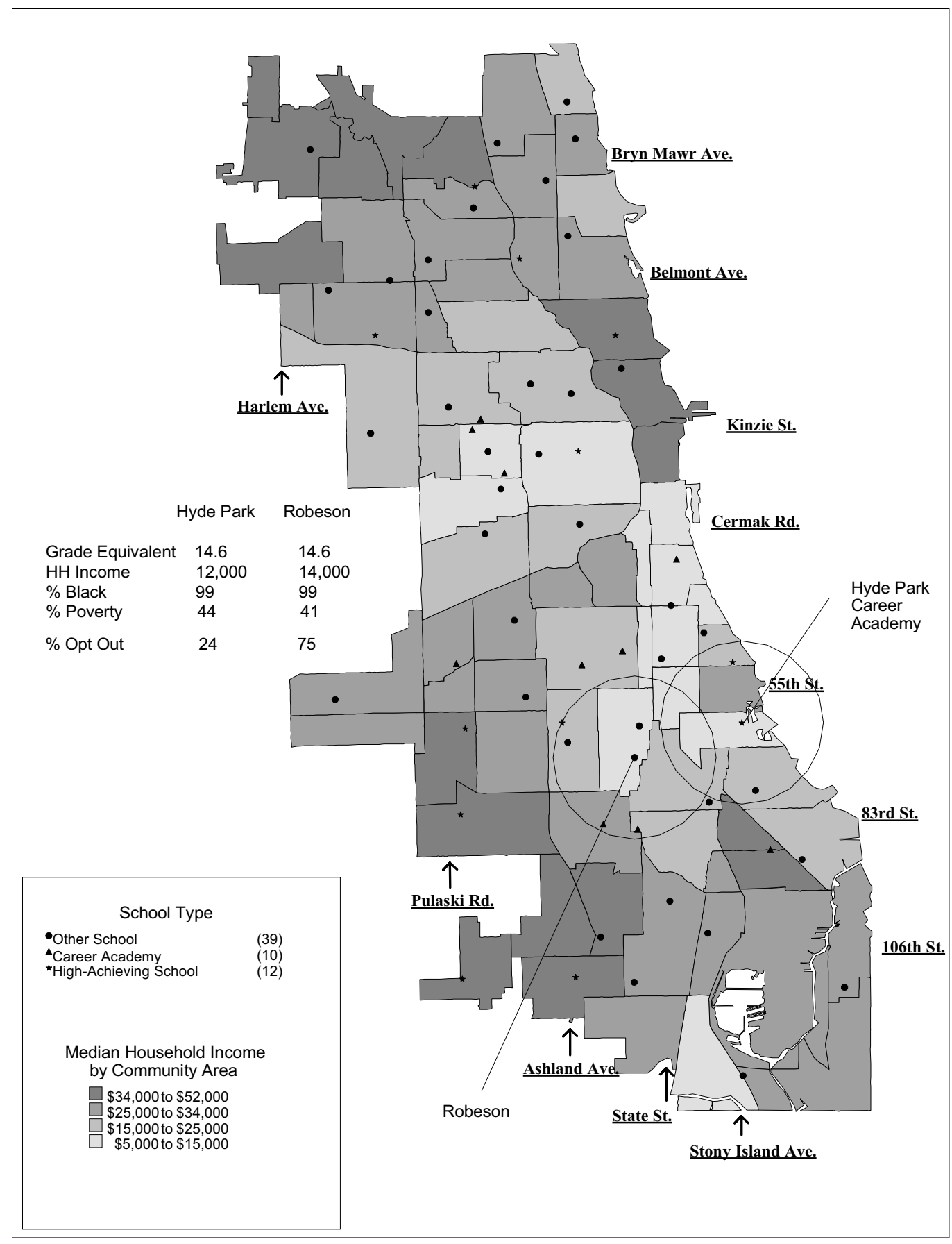


Table 1: Summary Statistics

\begin{tabular}{|c|c|c|c|c|c|c|}
\hline \multirow[b]{3}{*}{ Student Characteristics } & \multirow[b]{2}{*}{ All Students } & \multirow[b]{2}{*}{$\begin{array}{c}\text { Students Leaving } \\
\text { the CPS }\end{array}$} & \multirow{2}{*}{$\begin{array}{l}\text { Students } \\
\text { Remaining in } \\
\text { the CPS }\end{array}$} & \multicolumn{3}{|c|}{ Students Remaining in the CPS } \\
\hline & & & & $\begin{array}{l}\text { Non-Black/ } \\
\text { Non-Hispanic }\end{array}$ & Black & Hispanic \\
\hline & & & & & & \\
\hline 8th Grade Math Test Score & $\begin{array}{c}7.64 \\
(1.36)\end{array}$ & $\begin{array}{c}7.59 \\
(1.32)\end{array}$ & $\begin{array}{c}7.64 \\
(1.37)\end{array}$ & $\begin{array}{c}8.63 \\
(1.57)\end{array}$ & $\begin{array}{c}7.43 \\
(1.27)\end{array}$ & $\begin{array}{c}7.70 \\
(1.31)\end{array}$ \\
\hline 8th Grade Reading Test Score & $\begin{array}{c}7.49 \\
(1.86)\end{array}$ & $\begin{array}{c}7.46 \\
(1.86)\end{array}$ & $\begin{array}{c}7.49 \\
(1.86)\end{array}$ & $\begin{array}{c}8.59 \\
(2.03)\end{array}$ & $\begin{array}{c}7.31 \\
(1.78)\end{array}$ & $\begin{array}{c}7.43 \\
(1.82)\end{array}$ \\
\hline Completes $9^{\text {th }}$ grade at grade-level & $0.964^{\dagger}$ & - & 0.964 & 0.969 & 0.967 & 0.957 \\
\hline Completes $10^{\text {th }}$ grade at grade-level & $0.753^{\dagger}$ & - & 0.752 & 0.835 & 0.731 & 0.766 \\
\hline Completes $11^{\text {th }}$ grade at grade-level & $0.599^{\dagger}$ & - & 0.599 & 0.733 & 0.561 & 0.625 \\
\hline Graduates in 4 years & $0.503^{\dagger}$ & - & 0.503 & 0.657 & 0.462 & 0.528 \\
\hline Male & 0.485 & 0.525 & 0.479 & 0.501 & 0.468 & 0.496 \\
\hline Black & 0.595 & 0.481 & 0.610 & 0 & 1 & 0 \\
\hline Hispanic & 0.281 & 0.336 & 0.273 & 0 & 0 & 1 \\
\hline Age in September of 9th Grade & $\begin{array}{l}14.6 \\
(0.5)\end{array}$ & $\begin{array}{l}14.6 \\
(0.5)\end{array}$ & $\begin{array}{l}14.6 \\
(0.5)\end{array}$ & $\begin{array}{l}14.6 \\
(0.5)\end{array}$ & $\begin{array}{l}14.6 \\
(0.5)\end{array}$ & $\begin{array}{l}14.6 \\
(0.5)\end{array}$ \\
\hline Special Education Student in 8th Grade & 0.102 & 0.107 & 0.102 & 0.098 & 0.109 & 0.088 \\
\hline Lives with One or Both Parents & 0.909 & 0.893 & 0.911 & 0.917 & 0.904 & 0.923 \\
\hline Moved Tracts Between $8^{\text {th }}$ and 9th Grade & 0.116 & 0.121 & 0.115 & 0.083 & 0.124 & 0.110 \\
\hline Social Status Indicator (Block Level) & $\begin{array}{l}-0.298 \\
(0.675) \\
\end{array}$ & $\begin{array}{l}-0.255 \\
(0.680) \\
\end{array}$ & $\begin{array}{l}-0.303 \\
(0.674) \\
\end{array}$ & $\begin{array}{c}0.114 \\
(0.652) \\
\end{array}$ & $\begin{array}{l}-0.297 \\
(0.660) \\
\end{array}$ & $\begin{array}{l}-0.497 \\
(0.629) \\
\end{array}$ \\
\hline \multicolumn{7}{|l|}{ Tract Characteristics } \\
\hline $\begin{array}{l}\text { Average 8th Grade Math and Reading } \\
\text { Combined Score Among Peers in Tract }\end{array}$ & $\begin{array}{l}15.04 \\
(1.09)\end{array}$ & $\begin{array}{l}15.21 \\
(1.10)\end{array}$ & $\begin{array}{l}15.02 \\
(1.09)\end{array}$ & $\begin{array}{l}16.25 \\
(1.36)\end{array}$ & $\begin{array}{l}14.71 \\
(0.90)\end{array}$ & $\begin{array}{l}15.19 \\
(0.91)\end{array}$ \\
\hline $\begin{array}{l}\text { Average 8th Grade Combined Score } \\
\text { Among Peers in Assigned School }\end{array}$ & $\begin{array}{l}15.13 \\
(0.69)\end{array}$ & $\begin{array}{l}15.25 \\
(0.71)\end{array}$ & $\begin{array}{l}15.11 \\
(0.69)\end{array}$ & $\begin{array}{l}15.84 \\
(0.84)\end{array}$ & $\begin{array}{l}14.91 \\
(0.58)\end{array}$ & $\begin{array}{l}15.25 \\
(0.59)\end{array}$ \\
\hline Population & $\begin{array}{c}4,882 \\
(2,859)\end{array}$ & $\begin{array}{c}5,085 \\
(3,011)\end{array}$ & $\begin{array}{c}4,855 \\
(2,836)\end{array}$ & $\begin{array}{c}5,392 \\
(2,816)\end{array}$ & $\begin{array}{c}4,720 \\
(2,923)\end{array}$ & $\begin{array}{c}4,924 \\
(2,610)\end{array}$ \\
\hline$\%$ School Age & $\begin{array}{c}0.235 \\
(0.065)\end{array}$ & $\begin{array}{c}0.227 \\
(0.063)\end{array}$ & $\begin{array}{c}0.236 \\
(0.066)\end{array}$ & $\begin{array}{c}0.176 \\
(0.051)\end{array}$ & $\begin{array}{c}0.250 \\
(0.065)\end{array}$ & $\begin{array}{c}0.232 \\
(0.059)\end{array}$ \\
\hline$\%$ Hispanic & $\begin{array}{c}0.217 \\
(0.288) \\
\end{array}$ & $\begin{array}{c}0.252 \\
(0.293) \\
\end{array}$ & $\begin{array}{c}0.212 \\
(0.287) \\
\end{array}$ & $\begin{array}{c}0.215 \\
(0.191) \\
\end{array}$ & $\begin{array}{c}0.063 \\
(0.153) \\
\end{array}$ & $\begin{array}{c}0.542 \\
(0.275) \\
\end{array}$ \\
\hline
\end{tabular}




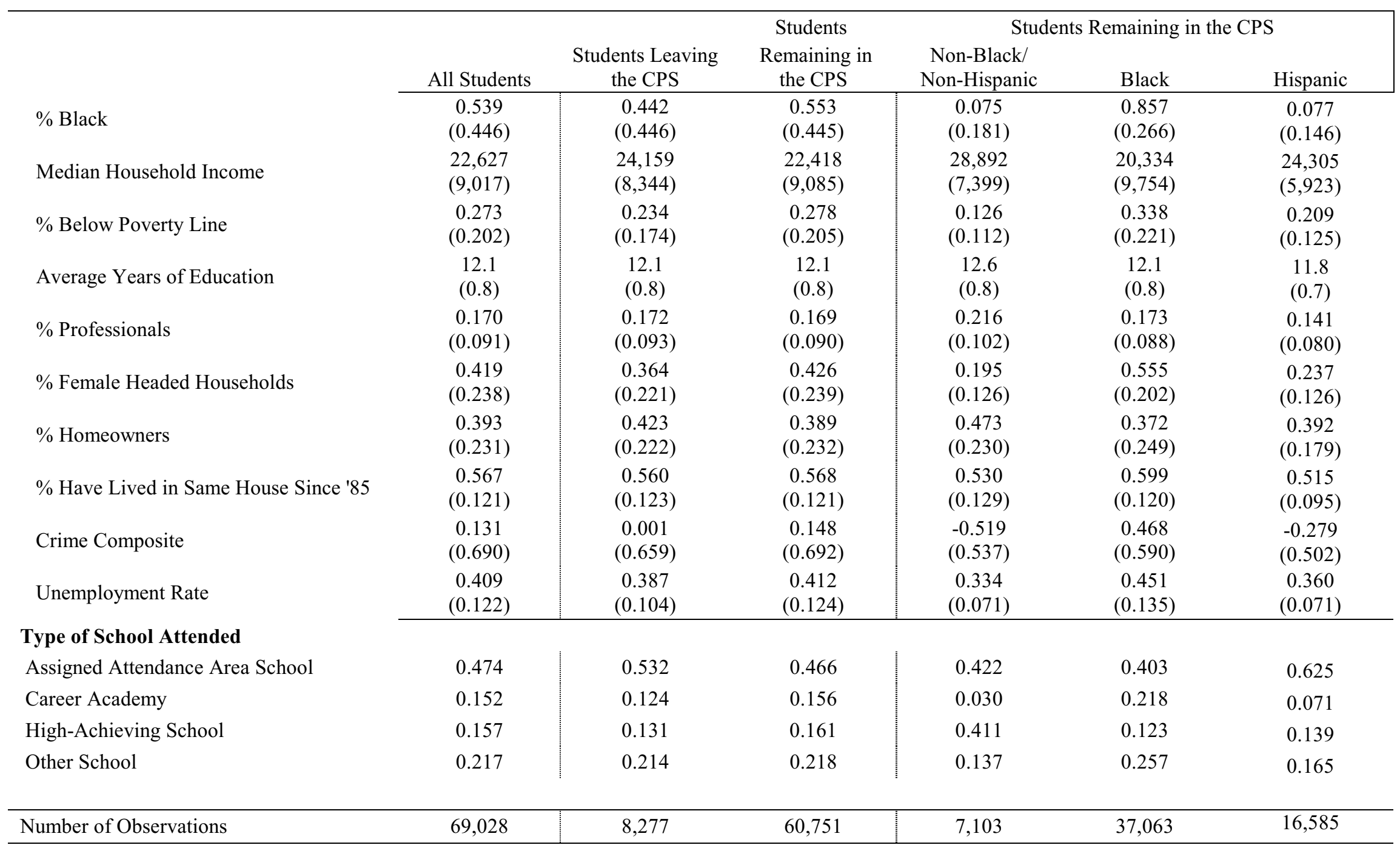

Notes to Table 1: Each column presents summary statistics for a separate sample. The sample represented in column 1 is our base sample of students enrolled in $9^{\text {th }}$ grade in the Fall of 1993,1994 , or 1995 who took the $8^{\text {th }}$-grade achievement tests in the Spring of the prior year. We rely on this sample to analyze the basic patterns of school choice. For the rest of the analyses focusing on student outcomes, we restrict our attention to the sub-sample of students who continue to attend schools within the CPS through high school. The majority of the students who leave the CPS move outside the Chicago area. The sub-sample that leaves is described in column 2, while columns 3-6 provide breakdowns for the sub-sample of students who remain. Standard deviations are in parentheses. ${ }^{\dagger}$ Grade completion and graduation are defined only for students who remain within the CPS. 
Table 2: Characteristics of CPS High Schools

\begin{tabular}{lccc}
\hline Characteristics of $9^{\text {th }}$ Graders & $\begin{array}{c}\text { Career } \\
\text { Academies }\end{array}$ & $\begin{array}{c}\text { High-Achieving } \\
\text { Schools }\end{array}$ & Other Schools \\
\hline Average $8^{\text {th }}$ Grade Math Score & 7.44 & 8.70 & 7.24 \\
Average $8^{\text {th }}$ Grade Reading Score & $(0.49)$ & $(0.67)$ & $(0.34)$ \\
& 7.29 & 8.86 & 6.96 \\
\% Black & $(0.69)$ & $(0.80)$ & $(0.43)$ \\
& 0.850 & 0.543 & 0.606 \\
\% Hispanic & $(0.234)$ & $(0.299)$ & $(0.395)$ \\
& 0.125 & 0.207 & 0.300 \\
\% Lives with Both Parents & $(0.197)$ & $(0.152)$ & $(0.328)$ \\
Average Social Status (block level) & 0.910 & 0.929 & 0.900 \\
& $(0.025)$ & $(0.015)$ & $(0.022)$ \\
Average Distance Traveled & -0.473 & -0.015 & -0.355 \\
& $(0.242)$ & $(0.275)$ & $(0.377)$ \\
\hline Number of Schools & 2.21 & 3.30 & 1.59 \\
\end{tabular}

Notes to Table 2: The three columns present characteristics of the student bodies at the three types of high schools within CPS. High-achieving schools are the top quintile based on $8^{\text {th }}$ grade achievement scores of the entering $9^{\text {th }}$ grade class. "Other schools" are the remaining low-achieving schools that are not career academies. Standard deviations across schools are shown in parentheses. 


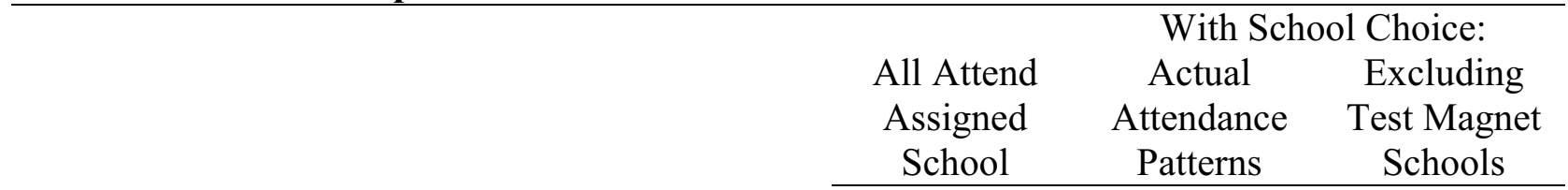

Variance in $8^{\text {th }}$ Grade Test Scores Within Schools

\begin{tabular}{lc|cc} 
Math & 1.77 & 1.28 & 1.30 \\
& $(0.35)$ & $(0.41)$ & $(0.42)$ \\
Reading & 3.32 & 2.51 & 2.56 \\
& $(0.47)$ & $(0.65)$ & $(0.63)$
\end{tabular}

Variance in $8^{\text {th }}$ Grade Test Scores Across Schools

Math

0.13

0.53

0.31

Reading

0.23

0.87

0.54

Fraction in Schools with Peer Cohort at or above the Minimum Academic Standard
$>15 \%$ Exceeding National Norm in Math
0.656
0.395
0.354
$>15 \%$ Exceeding National Norm in Reading
0.957
0.579
0.551

Fraction in Schools within Official Desegregation Reporting Categories
$\%$ Black $\geq 85$
0.430
0.421
0.441
$\%$ Hispanic $\geq 85$
0.049
0.069
0.074
$(\%$ Black $+\%$ Hispanic $) \geq 85$
0.691
0.675
0.713
$(\%$ Black $+\%$ Hispanic $) \geq 70$
0.839
$(\%$ Black $+\%$ Hispanic $)<70$
0.161
0.800
0.847
0.200
0.154

\footnotetext{
Number of Observations

69,028

69,028

64,698

Notes to Table 3: The results are based on the full sample of students enrolled in $9^{\text {th }}$ grade in the Fall of either 1993, 1994, and 1995 who took the $8^{\text {th }}$ grade achievement exams in the prior year. The first column shows statistics for the counterfactual in which all students attend their neighborhood school. The second column presents statistics given actual attendance patterns, and the third presents the same excluding students who attend the three selective test magnet schools from the sample. Whether a student's $9^{\text {th }}$ grade class satisfies the minimum academic standards is determined from the attending students' $8^{\text {th }}$ grade test scores.
} 
Table 4: Cross-sectional Relationship Between Travelling and Achievement

\begin{tabular}{|c|c|c|c|}
\hline Independent Variable & $\begin{array}{c}\text { Completes } 10^{\text {th }} \\
\text { Grade }\end{array}$ & $\begin{array}{c}\text { Completes } 11^{\text {th }} \\
\text { Grade }\end{array}$ & $\begin{array}{c}\text { Graduates High } \\
\text { School } \\
\end{array}$ \\
\hline Opts Out of Assigned School & $\begin{array}{c}0.066 \\
(0.006)\end{array}$ & $\begin{array}{c}0.084 \\
(0.006)\end{array}$ & $\begin{array}{c}0.075 \\
(0.005)\end{array}$ \\
\hline $8^{\text {th }}$ Grade Math Test Score & $\begin{array}{c}0.050 \\
(0.002)\end{array}$ & $\begin{array}{c}0.070 \\
(0.002)\end{array}$ & $\begin{array}{c}0.078 \\
(0.002)\end{array}$ \\
\hline $8^{\text {th }}$ Grade Reading Test Score & $\begin{array}{c}0.011 \\
(0.001)\end{array}$ & $\begin{array}{c}0.016 \\
(0.002)\end{array}$ & $\begin{array}{c}0.016 \\
(0.002)\end{array}$ \\
\hline Male & $\begin{array}{l}-0.036 \\
(0.008)\end{array}$ & $\begin{array}{l}-0.065 \\
(0.010)\end{array}$ & $\begin{array}{l}-0.085 \\
(0.010)\end{array}$ \\
\hline Black & $\begin{array}{c}0.036 \\
(0.011)\end{array}$ & $\begin{array}{c}0.006 \\
(0.013)\end{array}$ & $\begin{array}{l}-0.004 \\
(0.013)\end{array}$ \\
\hline Hispanic & $\begin{array}{c}0.045 \\
(0.009)\end{array}$ & $\begin{array}{c}0.035 \\
(0.011)\end{array}$ & $\begin{array}{c}0.030 \\
(0.011)\end{array}$ \\
\hline Black Male & $\begin{array}{l}-0.061 \\
(0.009)\end{array}$ & $\begin{array}{l}-0.077 \\
(0.011)\end{array}$ & $\begin{array}{l}-0.071 \\
(0.011)\end{array}$ \\
\hline Hispanic Male & $\begin{array}{l}-0.018 \\
(0.010)\end{array}$ & $\begin{array}{l}-0.023 \\
(0.013)\end{array}$ & $\begin{array}{l}-0.038 \\
(0.013)\end{array}$ \\
\hline Age in September $9^{\text {th }}$ Grade & $\begin{array}{l}-0.100 \\
(0.004)\end{array}$ & $\begin{array}{l}-0.101 \\
(0.004)\end{array}$ & $\begin{array}{l}-0.099 \\
(0.004)\end{array}$ \\
\hline In Special Education in $8^{\text {th }}$ Grade & $\begin{array}{c}0.031 \\
(0.007)\end{array}$ & $\begin{array}{c}0.052 \\
(0.008)\end{array}$ & $\begin{array}{c}0.067 \\
(0.007)\end{array}$ \\
\hline Moved Tracts Between $8^{\text {th }}$ and $9^{\text {th }}$ & $\begin{array}{l}-0.058 \\
(0.006)\end{array}$ & $\begin{array}{l}-0.069 \\
(0.006)\end{array}$ & $\begin{array}{l}-0.065 \\
(0.006)\end{array}$ \\
\hline Lives with Either or Both Parents & $\begin{array}{c}0.022 \\
(0.006)\end{array}$ & $\begin{array}{c}0.035 \\
(0.007)\end{array}$ & $\begin{array}{c}0.041 \\
(0.007)\end{array}$ \\
\hline Social Status Indicator (Block Level) & $\begin{array}{c}0.015 \\
(0.005)\end{array}$ & $\begin{array}{c}0.011 \\
(0.005)\end{array}$ & $\begin{array}{c}0.013 \\
(0.005)\end{array}$ \\
\hline $\mathrm{R}^{2}$ & 0.113 & 0.147 & 0.159 \\
\hline Number of Observations & 60,623 & 60,623 & 60,623 \\
\hline $\begin{array}{l}\text { Coefficient on Opts Out with only Cohort } \\
\text { Controls }\end{array}$ & $\begin{array}{c}0.124 \\
(0.007)\end{array}$ & $\begin{array}{c}0.160 \\
(0.007)\end{array}$ & $\begin{array}{c}0.158 \\
(0.007)\end{array}$ \\
\hline $\begin{array}{l}\text { Coefficient on Opts Out with Cohort, } \\
\text { Student Demographic and Tract } \\
\text { Characteristics as Control Variables }\end{array}$ & $\begin{array}{c}0.108 \\
(0.006)\end{array}$ & $\begin{array}{c}0.143 \\
(0.006)\end{array}$ & $\begin{array}{c}0.139 \\
(0.005)\end{array}$ \\
\hline $\begin{array}{l}\text { Coefficient on Opts Out with Only } 8^{\text {th }} \text { Grade } \\
\text { Test Scores as Controls }\end{array}$ & $\begin{array}{c}0.062 \\
(0.006)\end{array}$ & $\begin{array}{c}0.076 \\
(0.006)\end{array}$ & $\begin{array}{c}0.068 \\
(0.006)\end{array}$ \\
\hline
\end{tabular}

Notes to Table 4: Each column corresponds to a separate ordinary least squares regression for the binary dependent variable indicated. The models are linear probability models. The sample is the sub-sample of students enrolled in $9^{\text {th }}$ grade in the Fall of either 1993,1994 , or 1995 who took the $8^{\text {th }}$ grade achievement exams in the prior year who remain within the Chicago Public School system through high school. In addition to the control variables shown, each regression also includes the average $8^{\text {th }}$ grade math and reading combined score among peers in the student's tract and among peers assigned to the same attendance area school. The specifications also include the following tract-level covariates: population, crime index, unemployment rate, mean years of education, median household income, and the percentage Black, Hispanic, homeowners, female-headed households, below the poverty line, school aged children, professionals and in same house since 1985. Standard errors, shown in parentheses, are corrected for correlation within tracts using White's generalized method. 
Table 5: Variation in the Value of Opting Out

\begin{tabular}{|c|c|c|c|}
\hline & $\begin{array}{c}\text { Completes } 10^{\text {th }} \\
\text { Grade }\end{array}$ & $\begin{array}{c}\text { Completes } 11^{\text {th }} \\
\text { Grade }\end{array}$ & $\begin{array}{c}\text { Graduates High } \\
\text { School }\end{array}$ \\
\hline \multicolumn{4}{|l|}{ By Student's $8^{\text {th }}$ Grade Combined Test Scores } \\
\hline Top quartile & $\begin{array}{c}0.073 \\
(0.008)\end{array}$ & $\begin{array}{c}0.090 \\
(0.009)\end{array}$ & $\begin{array}{c}0.071 \\
(0.010)\end{array}$ \\
\hline $2^{\text {nd }}$ quartile & $\begin{array}{c}0.067 \\
(0.008)\end{array}$ & $\begin{array}{c}0.082 \\
(0.009)\end{array}$ & $\begin{array}{c}0.071 \\
(0.009)\end{array}$ \\
\hline $3^{\text {rd }}$ quartile & $\begin{array}{c}0.062 \\
(0.009)\end{array}$ & $\begin{array}{c}0.089 \\
(0.010)\end{array}$ & $\begin{array}{l}0.078 \\
(0.009)\end{array}$ \\
\hline Bottom quartile & $\begin{array}{c}0.056 \\
(0.011) \\
\end{array}$ & $\begin{array}{c}0.064 \\
(0.010) \\
\end{array}$ & $\begin{array}{c}0.063 \\
(0.009) \\
\end{array}$ \\
\hline \multicolumn{4}{|l|}{ By Student Race/Ethnicity } \\
\hline Non-Black/Non-Hispanic & $\begin{array}{c}0.083 \\
(0.013)\end{array}$ & $\begin{array}{c}0.106 \\
(0.014)\end{array}$ & $\begin{array}{c}0.107 \\
(0.014)\end{array}$ \\
\hline Black & $\begin{array}{c}0.068 \\
(0.008)\end{array}$ & $\begin{array}{c}0.088 \\
(0.007)\end{array}$ & $\begin{array}{c}0.076 \\
(0.007)\end{array}$ \\
\hline Hispanic & $\begin{array}{c}0.046 \\
(0.010)\end{array}$ & $\begin{array}{c}0.061 \\
(0.010)\end{array}$ & $\begin{array}{c}0.063 \\
(0.011) \\
\end{array}$ \\
\hline \multicolumn{4}{|l|}{ By Peer Ability in School Attends } \\
\hline More than 2 Grade Equivalents Higher than AA & $\begin{array}{c}0.107 \\
(0.006)\end{array}$ & $\begin{array}{c}0.137 \\
(0.006)\end{array}$ & $\begin{array}{c}0.129 \\
(0.007)\end{array}$ \\
\hline 1-2 Grade Equivalents Higher than AA & $\begin{array}{c}0.089 \\
(0.007)\end{array}$ & $\begin{array}{c}0.106 \\
(0.008)\end{array}$ & $\begin{array}{c}0.088 \\
(0.008)\end{array}$ \\
\hline Up to 1 Grade Equivalent Higher than AA & $\begin{array}{c}0.040 \\
(0.008)\end{array}$ & $\begin{array}{c}0.054 \\
(0.008)\end{array}$ & $\begin{array}{c}0.046 \\
(0.007)\end{array}$ \\
\hline Lower than AA & $\begin{array}{c}0.007 \\
(0.010) \\
\end{array}$ & $\begin{array}{c}0.009 \\
(0.010) \\
\end{array}$ & $\begin{array}{c}0.010 \\
(0.010) \\
\end{array}$ \\
\hline \multicolumn{4}{|l|}{ By Type of School Attends } \\
\hline Career Academy & $\begin{array}{c}0.105 \\
(0.007)\end{array}$ & $\begin{array}{c}0.108 \\
(0.008)\end{array}$ & $\begin{array}{c}0.077 \\
(0.007)\end{array}$ \\
\hline High-Achieving School & $\begin{array}{c}0.096 \\
(0.007)\end{array}$ & $\begin{array}{c}0.133 \\
(0.007)\end{array}$ & $\begin{array}{c}0.144 \\
(0.008)\end{array}$ \\
\hline Other School & $\begin{array}{c}0.030 \\
(0.007)\end{array}$ & $\begin{array}{c}0.047 \\
(0.007)\end{array}$ & $\begin{array}{c}0.042 \\
(0.006)\end{array}$ \\
\hline \multicolumn{4}{|l|}{ By Distance Traveled } \\
\hline Top Third (>3.7 miles) & $\begin{array}{c}0.064 \\
(0.007)\end{array}$ & $\begin{array}{c}0.082 \\
(0.007)\end{array}$ & $\begin{array}{c}0.084 \\
(0.007)\end{array}$ \\
\hline Middle Third (1.8-3.7 miles) & $\begin{array}{c}0.075 \\
(0.007)\end{array}$ & $\begin{array}{c}0.093 \\
(0.007)\end{array}$ & $\begin{array}{c}0.081 \\
(0.007)\end{array}$ \\
\hline Bottom Third $(<1.8$ miles $)$ & $\begin{array}{c}0.059 \\
(0.007)\end{array}$ & $\begin{array}{c}0.076 \\
(0.007)\end{array}$ & $\begin{array}{c}0.063 \\
(0.007)\end{array}$ \\
\hline
\end{tabular}

Notes to Table 5: In the top two panels, the coefficient on the variable for opting out is shown for a separate regression for the sub-sample indicated in each row. In the bottom panel, sets of coefficients are presented from specifications that include several types of travel as independent variables within the same model. The base sample and full set of control variables are as described in Table 4. Standard errors are corrected for correlation within tracts using White's generalized method. "Grade equivalent" refers to the combined test scores on $8^{\text {th }}$ grade math and reading achievement exams, and peer quality is calculated as the average of these combined test scores. "AA" stands for attendance area school. 
Table 6: The Impact of Distance on the Likelihood of Opting Out and the Probability of Graduating

Independent Variable

\begin{tabular}{|c|c|c|c|c|c|}
\hline $\begin{array}{l}\text { Predicted } \\
\text { Sign }\end{array}$ & $\begin{array}{c}\text { All } \\
\text { Students }\end{array}$ & I & II & III & IV \\
\hline
\end{tabular}

Ln(Miles from Attendance Area School)$$
\begin{array}{lllll}
0.115 & 0.123 & 0.130 & 0.114 & 0.094
\end{array}
$$$$
\begin{array}{lllll}
+ & (0.012) & (0.015) & (0.012) & (0.013)
\end{array}
$$

Ln(Miles from Closest Career Academy)

$-0.068$

$-0.041$

$-0.083$

$-0.105 \quad-0.043$

$\quad(0.013)$

$(0.016)$

(0.016)

(0.014)

(0.014)

Ln(Miles from Closest High-Achieving School)

$-0.029$

$-0.008$

$-0.009$

$-0.024$

$-0.060$

$\quad-\quad(0.011)$

(0.014)

(0.012)

$(0.014)$

$(0.013)$

Ln(Miles from Closest Other School)

$(0.019)$

$-0.089$

$-0.079$

$-0.064$

$-0.048$

$-$

$(0.023)$

$(0.021)$

(0.022)

$(0.021)$

\section{Dependent Variable $=$ Binary Indicator for Whether Student Graduates}

Ln(Miles from Attendance Area School)

Ln(Miles from Closest Career Academy)

Ln(Miles from Closest High-Achieving School)

$\begin{array}{llllll}? & -0.012 & -0.006 & -0.005 & -0.019 & -0.016\end{array}$

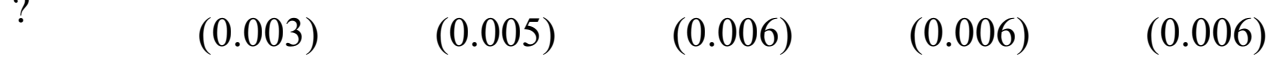

$\begin{array}{llllll}-0.026 & -0.024 & -0.031 & -0.028 & -0.019\end{array}$

$\begin{array}{lllll}- & (0.005) & (0.009) & (0.009) & (0.008)\end{array} \quad(0.007)$

Ln(Miles from Closest Other School)

Number of observations

\begin{tabular}{cccccc}
- & -0.006 & -0.007 & -0.014 & -0.008 & 0.004 \\
- & $(0.004)$ & $(0.009)$ & $(0.007)$ & $(0.007)$ & $(0.006)$ \\
& 0.003 & 0.000 & -0.007 & 0.025 & 0.001 \\
& $(0.007)$ & $(0.009)$ & $(0.013)$ & $(0.011)$ & $(0.011)$ \\
\hline & 60,623 & 14,898 & 15,017 & 15,221 & 15,487 \\
\hline
\end{tabular}

Notes to Table 6: The dependent variable in the specifications in the top panel is a binary indicator for whether a student opts out of the assigned school. The dependent variable in the specifications in the bottom panel is a binary indicator for whether a student graduates. The first column presents coefficients from regressions on the full sample described in Table 4. The next four columns present results from regressions on sub-samples based on quartiles of the overall student ability distribution. Student ability is measures by combined $8^{\text {th }}$ grade math and reading achievement test scores. Although only the coefficients on the distance variables are shown, the full set of covariates described in Table 4 is included. The distance measures are the logarithm of distance in miles from the centroid of the census tract that a student lives in to the type of school indicated. Standard errors (in parentheses) are corrected for correlation within tracts using White's generalized method. 
Table 7: Correlation Between Distances and Lagged Ability

\begin{tabular}{|c|c|c|c|c|}
\hline \multirow[b]{2}{*}{ Independent Variable } & \multicolumn{4}{|c|}{ Dependent Variable $=$ Ln(Miles) to: } \\
\hline & $\begin{array}{l}\text { Assigned } \\
\text { School }\end{array}$ & $\begin{array}{c}\text { Closest } \\
\text { Career } \\
\text { Academy } \\
\end{array}$ & $\begin{array}{c}\text { Closest High- } \\
\text { Achieving } \\
\text { School } \\
\end{array}$ & $\begin{array}{l}\text { Closest Other } \\
\text { School }\end{array}$ \\
\hline $8^{\text {th }}$ grade math score & $\begin{array}{c}0.005 \\
(0.004)\end{array}$ & $\begin{array}{l}-0.006 \\
(0.004)\end{array}$ & $\begin{array}{l}-0.002 \\
(0.003)\end{array}$ & $\begin{array}{l}-0.004 \\
(0.003)\end{array}$ \\
\hline $8^{\text {th }}$ grade reading score & $\begin{array}{l}-0.004 \\
(0.003)\end{array}$ & $\begin{array}{c}0.002 \\
(0.002)\end{array}$ & $\begin{array}{l}-0.000 \\
(0.002)\end{array}$ & $\begin{array}{c}0.002 \\
(0.002)\end{array}$ \\
\hline $\begin{array}{l}\text { Full set of covariates included } \\
\text { in the specification? }\end{array}$ & Yes & Yes & Yes & Yes \\
\hline $\begin{array}{l}\text { F-test: joint significance of } 8^{\text {th }} \\
\text { grade math and reading scores }\end{array}$ & $\begin{array}{c}\text { F-stat }=0.99 \\
{[p=0.37]}\end{array}$ & $\begin{array}{c}\text { F-stat }=2.59 \\
{[\mathrm{p}=0.08]}\end{array}$ & $\begin{array}{c}\text { F-stat }=1.00 \\
{[p=0.37]}\end{array}$ & $\begin{array}{c}\text { F-stat }=1.11 \\
{[p=0.33]}\end{array}$ \\
\hline
\end{tabular}

Notes to Table 7: The dependent variable in each column is the distance from the centroid of the census tract in which the student lives to the named school type. The top two rows present the estimated coefficients for $8^{\text {th }}$ grade math and reading test scores from regressions on the sample and including the full set of covariates described in Table 4. Standard errors (in parentheses) are corrected for correlation within tracts using White's generalized method. The third row presents F-statistics for tests of the joint significance of the two $8^{\text {th }}$ grade test scores (pvalues are in square brackets). 
Table 8: Testing for Evidence of Negative Externalities

\begin{tabular}{|c|c|c|c|c|c|}
\hline \multirow{3}{*}{ Independent Variable } & \multirow[b]{2}{*}{$\begin{array}{c}\text { All } \\
\text { Students }\end{array}$} & \multicolumn{4}{|c|}{ Student Ability Quartile (from lowest to highest) } \\
\hline & & I & II & III & IV \\
\hline & \multicolumn{5}{|c|}{ Dependent Variable $=$ Binary Indicator for Whether Graduates } \\
\hline Actual Peer Quality & $\begin{array}{c}0.024 \\
(0.002)\end{array}$ & $\begin{array}{c}0.021 \\
(0.005)\end{array}$ & $\begin{array}{c}0.027 \\
(0.005)\end{array}$ & $\begin{array}{c}0.027 \\
(0.004)\end{array}$ & $\begin{array}{c}0.024 \\
(0.002)\end{array}$ \\
\hline \multirow[t]{2}{*}{ Opts Out } & $\begin{array}{c}0.050 \\
(0.006)\end{array}$ & $\begin{array}{c}0.055 \\
(0.009)\end{array}$ & $\begin{array}{c}0.059 \\
(0.010)\end{array}$ & $\begin{array}{c}0.041 \\
(0.010)\end{array}$ & $\begin{array}{c}0.019 \\
(0.011)\end{array}$ \\
\hline & \multicolumn{5}{|c|}{ Dependent Variable $=$ Binary Indicator for Whether Graduates } \\
\hline Predicted Peer Quality & $\begin{array}{l}-.002 \\
(.005)\end{array}$ & $\begin{array}{l}-.023 \\
(.014)\end{array}$ & $\begin{array}{l}-.026 \\
(.014)\end{array}$ & $\begin{array}{l}-.009 \\
(.012)\end{array}$ & $\begin{array}{l}-.001 \\
(.006)\end{array}$ \\
\hline $\begin{array}{l}\text { Ln(Miles from Attendance } \\
\text { Area School) }\end{array}$ & $\begin{array}{l}-.018 \\
(.006)\end{array}$ & $\begin{array}{l}-.006 \\
(.005)\end{array}$ & $\begin{array}{l}-.005 \\
(.006)\end{array}$ & $\begin{array}{l}-.018 \\
(.006)\end{array}$ & $\begin{array}{l}-.014 \\
(.006)\end{array}$ \\
\hline $\begin{array}{l}\text { Ln(Miles from Closest } \\
\text { Career Academy) }\end{array}$ & $\begin{array}{l}-.026 \\
(.005)\end{array}$ & $\begin{array}{l}-.024 \\
(.008)\end{array}$ & $\begin{array}{l}-.034 \\
(.009)\end{array}$ & $\begin{array}{l}-.029 \\
(.008)\end{array}$ & $\begin{array}{l}-.019 \\
(.007)\end{array}$ \\
\hline $\begin{array}{l}\text { Ln(Miles from Closest } \\
\text { High-Achieving School) }\end{array}$ & $\begin{array}{l}-.007 \\
(.004)\end{array}$ & $\begin{array}{l}-.006 \\
(.009)\end{array}$ & $\begin{array}{l}-.014 \\
(.007)\end{array}$ & $\begin{array}{l}-.009 \\
(.007)\end{array}$ & $\begin{array}{l}.002 \\
(.006)\end{array}$ \\
\hline $\begin{array}{l}\text { Ln(Miles from Closest } \\
\text { Other School) }\end{array}$ & $\begin{array}{l}.003 \\
(.007)\end{array}$ & $\begin{array}{l}-.001 \\
(.009)\end{array}$ & $\begin{array}{l}-.005 \\
(.013)\end{array}$ & $\begin{array}{l}.026 \\
(.011)\end{array}$ & $\begin{array}{l}.001 \\
(.010)\end{array}$ \\
\hline Number of Observations & 60,623 & 14,898 & 15,017 & 15,221 & 15,487 \\
\hline \multicolumn{6}{|c|}{$\begin{array}{l}\text { Notes to Table 8: The dependent variable is a binary indicator for whether or not a student graduates high school. } \\
\text { Each column corresponds to a different sample, including the full sample and four samples for each ability quartile. } \\
\text { The top panel presents coefficients on actual peer quality and an indicator for opts out from a specification that } \\
\text { includes the full set of control variables described in Table } 4 \text {. Peer quality is measured as the average combined } 8^{\text {th }} \\
\text { grade math and reading scores of students in the school the student attends. The bottom panel presents the } \\
\text { coefficients on predicted peer quality and the distance measures that capture the likelihood that a student opts out. } \\
\text { The specification again includes the full set of covariates described in Table } 4 \text {. Peer quality is predicted as described } \\
\text { in the text. Standard errors are corrected for correlation within tracts using White's generalized method. }\end{array}$} \\
\hline
\end{tabular}




\begin{tabular}{|c|c|c|c|c|}
\hline \multirow[t]{2}{*}{ Independent Variable } & \multicolumn{4}{|c|}{$\begin{array}{c}\text { Dependent Variable = Binary Indicatory for } \\
\text { Whether Graduates }\end{array}$} \\
\hline & (1) & $(2)$ & (3) & (4) \\
\hline Opts Out to Career Academy & $\begin{array}{l}.077 \\
(.007)\end{array}$ & $\begin{array}{l}.106 \\
(.012)\end{array}$ & $\begin{array}{l}.021 \\
(.025)\end{array}$ & $\begin{array}{l}.027 \\
(.024)\end{array}$ \\
\hline Opts Out to High-Achieving School & $\begin{array}{l}.144 \\
(.008)\end{array}$ & $\begin{array}{l}.125 \\
(.010)\end{array}$ & $\begin{array}{l}.108 \\
(.013)\end{array}$ & $\begin{array}{l}.089 \\
(.013)\end{array}$ \\
\hline Opts Out to Other School & $\begin{array}{l}.042 \\
(.006)\end{array}$ & $\begin{array}{l}.044 \\
(.007)\end{array}$ & $\begin{array}{l}.035 \\
(.007)\end{array}$ & $\begin{array}{l}.033 \\
(.007)\end{array}$ \\
\hline Attendance Area School Sample & No & Yes & No & No \\
\hline School-Cohort Fixed Effects & No & No & Yes & Yes \\
\hline School-Cohort Fixed Effects $\times$ Ability Quartile & No & No & No & Yes \\
\hline Number of Observations & 60,623 & 46,513 & 60,623 & 60,623 \\
\hline
\end{tabular}

Notes to Table 9: Each column presents estimates from a separate specification. In each case, the dependent variables is a binary indicator for whether the student graduates and the full set of control variables from Table 4 are included as covariates. Only the coefficients (and standard errors) on the three indicators for opting out of the assigned school are shown. The first column presents our baseline estimates for the full sample of students described in Table 5. Because the impact of opting out is identified only from schools that have both assigned students and students who opt in once school fixed effects are included, the second column shows the baseline estimates for this sample of schools. The last two columns add school-cohort and school-cohort-ability quartile fixed effects, respectively. Standard errors, shown in parentheses, are corrected for correlation within tracts using White's generalized method. 